\title{
Disruption of a Neural Microcircuit in the Rod Pathway of the Mammalian Retina by Diabetes Mellitus
}

\author{
Áurea Castilho, ${ }^{1,2} \oplus^{\circledR A n t o ́ n i o ~ F . ~ A m b r o ́ s i o, ~}{ }^{2,3}$ Espen Hartveit, ${ }^{1}$ and ${ }^{\circledR}$ Margaret L. Veruki ${ }^{1}$ \\ ${ }^{1}$ Department of Biomedicine, University of Bergen, Bergen N-5009, Norway, ${ }^{2}$ Centre of Ophthalmology and Vision Sciences, Institute of Biomedical \\ Imaging and Life Sciences, Faculty of Medicine, University of Coimbra, Coimbra, Portugal 3000-548, and ${ }^{3}$ Association for Innovation and Biomedical \\ Research on Light and Image, Coimbra, Portugal 3000-548
}

Diabetes leads to dysfunction of the neural retina before and independent of classical microvascular diabetic retinopathy, but previous studies have failed to demonstrate which neurons and circuits are affected at the earliest stages. Here, using patch-clamp recording and two-photon $\mathrm{Ca}^{2+}$ imaging in rat retinal slices, we investigated diabetes-evoked changes in a microcircuit consisting of rod bipolar cells and their dyad postsynaptic targets, AII and A17 amacrine cells, which play an essential role in processing scotopic visual signals. AII amacrines forward their signals to ON- and OFF-cone bipolar cells and A17 amacrines provide GABAergic feedback inhibition to rod bipolar cells. Whereas $\mathrm{Ca}^{2+}$-permeable AMPA receptors mediate input from rod bipolar cells to both AII and A17 amacrines, diabetes changes the synaptic receptors on A17, but not AII amacrine cells. This was expressed as a change in pharmacological properties and single-channel conductance of the synaptic receptors, consistent with an upregulation of the AMPA receptor GluA2 subunit and reduced $\mathrm{Ca}^{2+}$ permeability. In addition, two-photon imaging revealed reduced agonist-evoked influx of $\mathrm{Ca}^{2+}$ in dendritic varicosities of $\mathrm{A} 17$ amacrine cells from diabetic compared with normal animals. Because $\mathrm{Ca}^{2+}$-permeable receptors in A17 amacrine cells mediate synaptic release of $\mathrm{GABA}$, the reduced $\mathrm{Ca}^{2+}$ permeability of these receptors in diabetic animals leads to reduced release of GABA, followed by disinhibition and increased release of glutamate from rod bipolar cells. This perturbation of neuron and microcircuit dynamics can explain the decreased dynamic range and sensitivity of scotopic vision that has been observed in diabetes.

Key words: amacrine cells; calcium-permeable AMPA receptors; diabetes; retina

\section{Introduction}

Dysfunction of ion channels and receptors important for synaptic communication is thought to be at the core of deficits associated with neuropathological disorders, such as Alzheimer's disease, Parkinson's disease, schizophrenia, and autism (Sheng et al., 2012; Zoghbi and Bear, 2012). However, establishing causal links between a specific molecular pathology, the consequent microcircuit dysfunction, and the ultimate neurological impairment is challenging. Thus, it is advantageous to directly study physiological signaling within identified neural microcircuits and well defined animal disease models.

\footnotetext{
Received Dec. 29, 2014; revised Feb. 3, 2015; accepted Feb. 19, 2015.

Author contributions: Á.C., A.F.A., E.H., and M.L.V. designed research; Á.C., E.H., and M.L.V. performed research; E.H. contributed unpublished reagents/analytic tools; Á.C., E.H., and M.L.V. analyzed data; E.H. and M.L.V. wrote the paper.

This work was supported by the Portuguese Foundation for Science and Technology and COMPETE-FEDER (PTDC/ SAU-NEU/71228/2006, to A.F.A.; SFRH/BD/30235/2006 to Á.C.), the Research Council of Norway (NFR 178105, 182743,189662 , to E.H.; NFR 213776 to M.L.V.), the Western Norway Regional Health Authority (911349 to E.H.), the Odd Fellow Medical Sciences Research Fund (to E.H.), the Asta and Mikael Aksdal Medical Sciences Research Fund (to E.H.), and the Department of Biomedicine (University of Bergen). We thank Bayer Norway for generously providing glucometers and test strips and Torhild Fjordheim Sunde for excellent technical assistance.

The authors declare no competing financial interests.

Correspondence should be addressed to either Margaret L. Veruki or Espen Hartveit, University of Bergen, Department of Biomedicine, Jonas Lies vei 91, N-5009 Bergen, Norway. E-mail: margaret.veruki@biomed.uib.no or espen.hartveit@biomed.uib.no.

DOI:10.1523/JNEUROSCI.5285-14.2015

Copyright $\odot 2015$ the authors $\quad 0270-6474 / 15 / 355422-12 \$ 15.00 / 0$
}

There is increasing evidence that a major complication of diabetes mellitus, diabetic retinopathy, partially reflects a dysfunction of the neural retina that precedes the microvascular pathology associated with later stages of the disease (Antonetti et al., 2012; Simó and Hernández, 2014). In this sense, prevascular diabetic retinopathy reflects a primary neuropathological disorder with evidence for changes in the functional state of several neurotransmitter systems, including levels of glutamate and GABA, and the expression of AMPA receptor (AMPAR) subunits (Ng et al., 2004; Ramsey et al., 2006, 2007; Santiago et al., 2006, 2008; Semkova et al., 2010; Gowda et al., 2011; Castilho et al., 2012). Of particular interest is the regulation of the AMPAR GluA2 subunit, which is a key determinant of functional properties of AMPARs (including $\mathrm{Ca}^{2+}$ permeability, single-channel conductance and kinetics; Cull-Candy et al., 2006; Traynelis et al., 2010) and has been implicated in neurodegenerative disorders (Weiss, 2011). Although the majority of AMPARs in the retina are likely to contain GluA2 and thus display low $\mathrm{Ca}^{2+}$ permeability, receptors with significant $\mathrm{Ca}^{2+}$ permeability are found in several cell types and contribute to normal synaptic transmission (Diamond, 2011). It is a considerable challenge, however, to establish a mechanistic connection between diabetes-evoked changes at the molecular level and visual dysfunction detected in diabetic patients or animals.

Here, by using an experimental model of diabetes in mature rats and directly studying synaptic transmission in an 
A
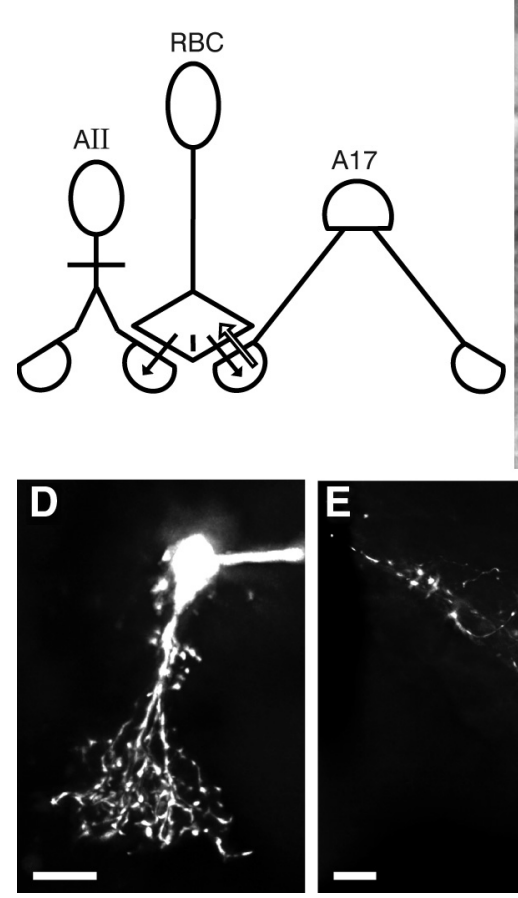
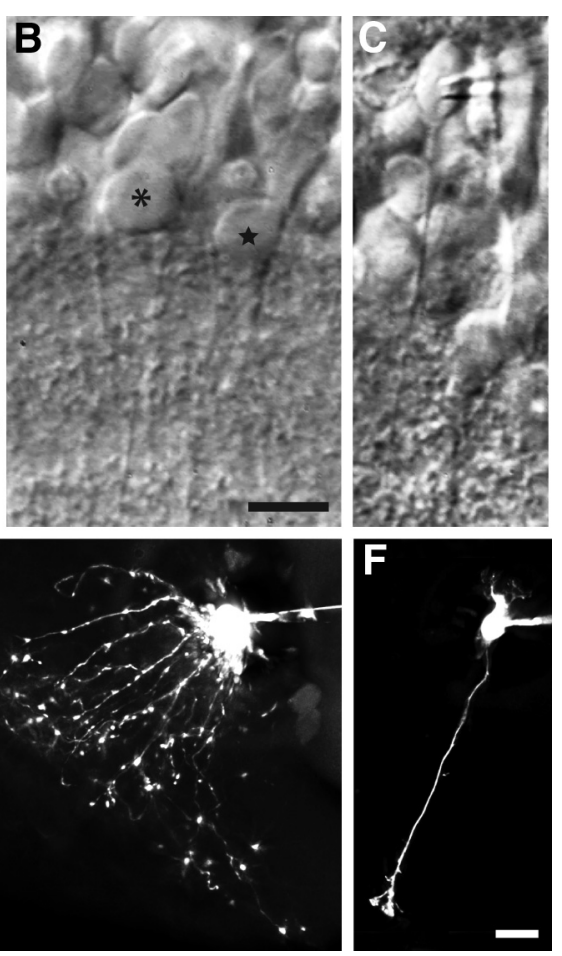

Figure 1. Rod amacrine (All and $A 17$ ) and RBCs in the rat retinal slice preparation. $A$, Schematic diagram of retinal microcircuit consisting of an RBC and All and A17 amacrine cells, henceforth referred to as the RBC-All-A17 microcircuit. Arrows indicate direction and sign of synaptic transmission between the various cellular elements: feedforward glutamatergic transmission from RBCs to All and A17 amacrines (solid arrows) and feedback GABAergic transmission from A17 amacrine to RBC (reciprocal synapse; open arrow). B, IR-DIC videomicrograph of a retinal slice with cell bodies of an A17 (asterisk) and an All (star) amacrine cell, both located at the border between the inner nuclear layer and the inner plexiform layer. Scale bar, $10 \mu \mathrm{m}$. C, IR-DIC videomicrograph of a retinal slice with cell body of a $\mathrm{RBC}$ (targeted by patch pipette). Same scale as in $\boldsymbol{B}$. D, All amacrine cell filled with Alexa Fluor 488 via patch pipette. Maximum intensity projection (along z-axis) generated from wide-field fluorescence image stack after deconvolution (D-F). $\boldsymbol{E}$, A17 amacrine cell filled with Alexa Fluor 488 via patch pipette. $\boldsymbol{F}$, RBC filled with Alexa Fluor 594 via patch pipette. Scale bars: $\boldsymbol{D}-\boldsymbol{F}, 10 \mu \mathrm{m}$.

identified retinal microcircuit, we have examined how diabetes differentially affects the functional properties of synaptic AMPARs expressed by two well characterized rod amacrine cells (AII and A17; Fig. 1A), giving rise to marked changes in microcircuit functional dynamics. These amacrine cells constitute the dyad postsynaptic targets in the glutamatergic rod bipolar cell (RBC) microcircuit (Kolb and Famiglietti, 1974), with AII amacrines providing scotopic signals to ON- and OFF-channels (Demb and Singer, 2012; Hartveit and Veruki, 2012) and A17 amacrines providing reciprocal inhibition to RBCs (Diamond and Grimes, 2014). Whereas $\mathrm{Ca}^{2+}$-permeable AMPARs (CP-AMPARs) are involved in mediating synaptic input from RBCs to both AII and A17 amacrines (Singer and Diamond, 2003; Chávez et al., 2006; Osswald et al., 2007; Bowie, 2012), only the receptors of A17 amacrines are affected by diabetes, and the observed changes are consistent with an upregulation of the GluA2 subunit and a consequent reduction of $\mathrm{Ca}^{2+}$ permeability. Because CP-AMPARs in A17 amacrines mediate synaptic release of GABA (Chávez et al., 2006), the reduced $\mathrm{Ca}^{2+}$ permeability of these receptors diminishes the release of GABA, leading to disinhibition of RBCs and increased glutamate release from these cells.

\section{Materials and Methods}

Retinal slice preparation and visual targeting of neurons. General aspects of the methods were previously described in detail (Veruki et al., 2003). Female albino rats (Wistar HanTac; 5-8 weeks postnatal) were deeply anesthetized with isoflurane in oxygen and killed by cervical dislocation

(procedure approved under the surveillance of the Norwegian Animal Research Authority). Vertical retinal slices were visualized using either an Axioskop 2 FS (Zeiss) with a $40 \times$ water-immersion objective and infrared differential interference contrast (IR-DIC) videomicroscopy or an Olympus BX51WI with a $40 \times$ or $60 \times$ water-immersion objective and IRDIC or IR Dodt gradient contrast videomicroscopy (Luigs \& Neumann). For experiments with two-photon microscopy, the slices were visualized using a custom-modified "Movable Objective Microscope" (MOM; Sutter Instrument) with a $20 \times$ water-immersion objective $(0.95 \mathrm{NA}$; Olympus) and IR (780 nm LED; M780L2; Thorlabs) Dodt gradient contrast videomicroscopy. Recordings were performed at room temperature $\left(22-25^{\circ} \mathrm{C}\right)$.

AII amacrines were targeted based on the position of a cell body across the border of the inner nuclear layer (INL) and the inner plexiform layer (IPL), and the presence of a thick primary dendrite that tapers as it descends into the IPL (Fig. 1B). A17 amacrines were targeted based on the location of a dome-shaped cell body at the border of the INL and IPL (Fig. 1B). RBCs were targeted based on the location of a cell body at the distal end of the INL, close to the outer plexiform layer (Fig. 1C). For unequivocal identification, all cells were visualized with fluorescence microscopy following the recording (Fig. $1 D-F$ ). Altogether, we recorded from 86 AII amacrine cells (41 normal, 37 diabetic, 8 insulin-treated diabetic), 26 A17 amacrine cells (12 normal, 14 diabetic), and 19 RBCs (10 normal, 9 diabetic).

Solutions and drug application. The standard extracellular bath solution was continuously bubbled with $95 \% \mathrm{O}_{2}-5 \% \mathrm{CO}_{2}$ and had the following composition (in mM): $125 \mathrm{NaCl}, 25$ $\mathrm{NaHCO}_{3}, 2.5 \mathrm{KCl}, 2.5 \mathrm{CaCl}_{2}, 1 \mathrm{MgCl}_{2}, 10$ glucose, $\mathrm{pH}$ 7.4. For AII amacrine cells, recording pipettes were filled with the following (in $\mathrm{mm}$ ): 125 potassium gluconate, $8 \mathrm{KCl}, 5$ HEPES, $1 \mathrm{CaCl}_{2}, 1 \mathrm{MgCl}_{2}, 5$ EGTA, $4 \mathrm{Na}_{2} \mathrm{ATP}$, and $2 \mathrm{~N}-(2$, 6-dimethylphenylcarbamoylmethyl)triethylammonium bromide (QX314; Tocris Bioscience). $\mathrm{pH}$ was adjusted to 7.3 with $\mathrm{KOH}$. In some recordings, the bath solution contained $0.15 \mathrm{mM} \mathrm{CaCl}_{2}$ and $3.35 \mathrm{~mm}$ $\mathrm{MgCl}_{2}$ to reduce the frequency of spontaneous EPSCs (spEPSCs). For A17 amacrine cells, pipettes were filled with the following (in mM): 125 potassium gluconate, $8 \mathrm{NaCl}, 5 \mathrm{KCl}, 10 \mathrm{HEPES}, 0.2 \mathrm{EGTA}, 4$ magnesium ATP (MgATP), and 0.4 sodium GTP. pH was adjusted to 7.3 with $\mathrm{KOH}$. For RBCs, pipettes were filled with the following (in mM): $125 \mathrm{CsCl}, 8$ $\mathrm{NaCl}, 10$ HEPES, $1 \mathrm{CaCl}_{2}$, 5 EGTA, 15 TEA-Cl, and $4 \mathrm{MgATP}$. $\mathrm{pH}$ was adjusted to 7.3 with $\mathrm{CsOH}$. For visualization with fluorescence microscopy after the recording, we added either Lucifer yellow $(1 \mathrm{mg} / \mathrm{ml}$; Sigma-Aldrich), Alexa Fluor 488 (100 $\mu \mathrm{M}$; Invitrogen) or Alexa Fluor 594 (40 $\mu \mathrm{M}$; Invitrogen) to the intracellular solutions. For two-photon $\mathrm{Ca}^{2+}$ imaging in A17 amacrine cells, pipettes were filled with the A17 solution indicated above, but EGTA was replaced with Oregon Green 488 BAPTA-1 (OGB-1; $200 \mu \mathrm{m}$; Invitrogen) and Alexa Fluor $594(40 \mu \mathrm{M})$ was added for visualization of the cellular morphology. The data acquisition software (PatchMaster; HEKA Elektronik) corrected all holding potentials for liquid junction potentials on-line. Theoretical liquid junction potentials were calculated with JPCalcW (Molecular Devices).

Drugs were added directly to the extracellular solution at the following concentrations (supplied by Tocris Bioscience, unless otherwise indicated): $1 \mu \mathrm{M}$ strychnine (Research Biochemicals), $10 \mu \mathrm{M}$ (-)-bicuculline methochloride, $0.3 \mu \mathrm{M}$ tetrodotoxin (TTX), 100 or $200 \mu \mathrm{M}(1,2,5,6-$ tetrahydropyridin-4-yl)methylphosphinic acid (TPMPA), $10 \mu \mathrm{M}$ 
$N, N, H$,-trimethyl-5-[(tricyclo[3.3.1.13,7] dec-1-ylmethyl)amino]-1pentanaminiumbromide hydrobromide (IEM 1460), $50 \mu \mathrm{M}$ 5,7dihydroxytryptamine (5,7-DHT, creatinine sulfate salt, Sigma-Aldrich), and $20 \mu \mathrm{M}$ (RS)-3-(2-carboxypiperazin-4-yl)-propyl-1-phosphonic acid (CPP). With the exception of CPP and IEM 1460, the pharmacological agents used at the indicated concentrations do not to our knowledge block glutamate receptors on AII or A17 amacrine cells. Solutions were either made up freshly for each experiment or were prepared from concentrated aliquots stored at $-20^{\circ} \mathrm{C}$. Solutions with $5,7-\mathrm{DHT}$ also contained ascorbic acid $(100 \mu \mathrm{M})$ as an antioxidant and were protected from light.

In experiments with two-photon microscopy and $\mathrm{Ca}^{2+}$ imaging (see below), we used high-resolution microiontophoresis (Murnick et al., 2002) to activate glutamate receptors on A17 amacrine cells. Highresistance pipettes (80-90 M $\Omega$ ) were pulled (P-97; Sutter Instrument) from filamented borosilicate glass (outer diameter, $1.5 \mathrm{~mm}$; inner diameter, $0.86 \mathrm{~mm}$ ) and filled with $150 \mathrm{~mm}$ glutamate ( $\mathrm{pH}$ adjusted to 7.0 with $\mathrm{NaOH})$. Alexa Fluor $594(40 \mu \mathrm{M})$ was added for visualization of the pipette tip. The pipette capacitance was compensated by the microiontophoresis system (MVCS-C-02M; npi electronic). Brief (typically 0.6$1.0 \mathrm{~ms}$ ), negative current pulses (typically $200-600 \mathrm{nA}$ ) were applied to eject glutamate after the pipette tip was positioned close $(1-2 \mu \mathrm{m})$ to an A17 varicosity under visual control using two-photon microscopy.

Electrophysiological recording and data acquisition. Patch pipettes were pulled from thick-walled borosilicate glass (outer diameter, $1.5 \mathrm{~mm}$; inner diameter, $0.86 \mathrm{~mm}$ ). The open-tip resistance of the pipettes ranged from 4.5 to $8.5 \mathrm{M} \Omega$ when filled with intracellular solutions. Voltageclamp recordings were performed with an EPC9-dual, an EPC10-USBdual, or an EPC10-triple amplifier (HEKA Elektronik) controlled by PatchMaster software. After establishing a $\mathrm{G} \Omega$-seal, currents caused by the recording electrode capacitance $\left(C_{\text {fast }}\right)$ were automatically measured and neutralized by the amplifier. After breaking into the cell, currents caused by the cell membrane capacitance $\left(C_{\text {slow }}\right)$ were partially neutralized by the amplifier. The sampling interval was set between 10 and $50 \mu \mathrm{s}$ depending on the experiment. Before sampling, signals were low-pass filtered (analog 3- and 4-pole Bessel filters in series) with a corner frequency $(-3 \mathrm{~dB})$ of 4 or $5 \mathrm{kHz}$. Cells with a holding current more negative than $-80 \mathrm{pA}$ (at a holding potential of $-60 \mathrm{mV}$ ) or a series resistance $\left(R_{\mathrm{s}}\right)>30 \mathrm{M} \Omega$ were rejected. For $\mathrm{Ca}^{2+}$ imaging experiments with $\mathrm{A} 17$ amacrines, series resistances $\leq 60 \mathrm{M} \Omega$ were allowed.

During acquisition of spEPSCs, each epoch of continuous recording had a duration of $30 \mathrm{~s}$. Between each record, $R_{\mathrm{s}}$ was monitored by applying a series of $20 \mathrm{mV}$ hyperpolarizing voltage pulses (16 ms duration) after transiently disabling the $C_{\text {slow }}$ neutralization circuitry of the amplifier. The charging transients were analyzed on-line by FitMaster software (HEKA Elektronik) by fitting the decay phase during the voltage pulse with a double exponential function and $R_{\mathrm{s}}$ was calculated from the amplitude of the voltage pulse and the peak current amplitude extrapolated to the onset of the pulse. After each $30 \mathrm{~s}$ epoch of continuous recording, the data were exported to IGOR Pro (WaveMetrics) and the frequency of spEPSCs was displayed throughout the recording (spEPSCs were detected by routines written for IGOR Pro by T. Ishikawa, Jikei University, Japan).

Experimental model of type 1 diabetes. Diabetes was induced in 4-weekold rats with a single intraperitoneal injection of streptozotocin (65 $\mathrm{mg} / \mathrm{kg}$ body weight), a toxin selective for $\beta$ cells of the pancreatic islets. Streptozotocin was freshly dissolved in $10 \mathrm{~mm} \mathrm{Na}$-citrate buffer, $\mathrm{pH} 4.5$, and stored at $-20^{\circ} \mathrm{C}$ until immediately before use. After injection, each rat was returned to its home cage and tested for development of diabetes by measuring the blood glucose concentration $2 \mathrm{~d}$ later. Blood glucose was measured with a hand-held glucometer (Contour or Contour XT Glucometer, Bayer) by collecting a drop of blood from the tail. Rats with blood glucose concentration exceeding $250 \mathrm{mg} / \mathrm{dl}$ were considered diabetic. At the day of the experiment, diabetes was again verified by measuring blood glucose. Animals were kept on a $12 \mathrm{~h}$ light/dark cycle with ad libitum access to food and water.

When rats received treatment with insulin (Sigma-Aldrich), diabetes was first verified by measuring blood glucose $2 \mathrm{~d}$ after streptozotocin injection and then insulin was administered subcutaneously twice every day until the day of the experiment. During the first $2 \mathrm{~d}$ of insulin treatment, glucose concentration was measured twice daily and the dose of insulin was adjusted between 2 and 7 units to maintain the blood glucose concentration lower than $250 \mathrm{mg} / \mathrm{dl}$. After the third day of insulin treatment, we found that administration of 6 units of insulin twice each day resulted in adequate glucose levels and this treatment continued without further adjustments until the day of the experiment. During this period, blood glucose concentration was measured once daily, before the second injection of insulin.

Analysis of electrophysiological data. Data were analyzed offline with FitMaster, IGOR Pro, AxoGraph X (AxoGraph Scientific), Excel (Microsoft), MiniAnalysis (Synaptosoft), and GraphPad Prism (GraphPad Software). For detection of spEPSCs with MiniAnalysis, the threshold was set to 3-8 pA depending on the noise level and detected events were confirmed by eye. To quantify spEPSC amplitude reduction evoked by IEM 1460, we used the method of largest amplitude count matching (Stell and Mody, 2002). For kinetic analysis, we included only well separated spEPSCs (interevent interval $\geq 10 \mathrm{~ms}$ ) that appeared to rise in a monophasic fashion to a peak followed by an exponential decay. Before averaging, individual spEPSCs were aligned at the $50 \%$ rise time. The decay time course of individual and averaged spEPSCs was estimated by curve fitting with a single exponential function as follows:

$$
I(t)=A \exp (-t / \tau)+I_{s s}
$$

where $I(t)$ is the current as a function of time, $A$ is the amplitude at time $0, \tau$ is the time constant, and $I_{s s}$ is the steady-state current amplitude (typically zero).

For peak-scaled, nonstationary noise analysis of spEPSCs (for review, see Hartveit and Veruki, 2007), only well separated (interevent interval $>10 \mathrm{~ms}$ ), monophasic $(10-90 \%$ rise time $<1 \mathrm{~ms}$ ) events were included. The number of events included in the analysis for each cell ranged from 81 to 1215 . The ensemble variance was calculated from the difference current between each event and the ensemble mean. Before subtraction, the peak of the ensemble mean was scaled to the corresponding value of the spEPSC at the same point in time to correct for quantal and synaptic variability. The ensemble variance was plotted against the ensemble mean current (for the interval between the peak response and the end of the decay phase) and fitted with the parabolic function as follows:

$$
\sigma^{2}(I)=i I-I^{2} / N+\sigma_{b}^{2}
$$

where $\sigma^{2}(I)$ is the variance as a function of mean current, $i$ is the apparent single-channel current, $N$ is the average number of open channels at the spEPSC peak, and $\sigma_{b}^{2}$ is the variance of the background noise. The apparent single-channel chord conductance $(\gamma)$ was then calculated as follows:

$$
\gamma=i /\left(V_{\mathrm{m}}-E_{\mathrm{rev}}\right)
$$

from the known holding potential $\left(V_{\mathrm{m}}\right)$ and assuming a current reversal potential $\left(E_{\text {rev }}\right)$ of $0 \mathrm{mV}$.

For illustration purposes, most raw current records were low-pass filtered (digital Gaussian filter, $-3 \mathrm{~dB}$ at $500 \mathrm{~Hz}-2 \mathrm{kHz}$ ) or smoothed by a binomial smoothing function (IGOR Pro) to emphasize the kinetics of the response.

Wide-field fluorescence microscopy. In some experiments, we acquired image stacks of cells filled with fluorescent dye (Alexa Fluor 488 or Alexa Fluor 594), using a TILLvisION system (TILL Photonics). An image stack was acquired as a series of optical sections collected at temporal intervals of $500 \mathrm{~ms}$ and focal plane intervals of $0.5 \mu \mathrm{m}$, using a cooled, interline transfer CCD camera (Imago QE). The excitation light source (Polychrome V, $150 \mathrm{~W}$ xenon lamp) was coupled to the epifluorescence port of the microscope with a custom-made condensor via a quartz fiber-optic light guide. The wavelength of excitation light was $488 \mathrm{~nm}$ for Alexa Fluor 488 and $570 \mathrm{~nm}$ for Alexa Fluor 594 and the exposure time was 50 ms. At the total magnification used, the pixel size was $\sim 106 \mathrm{~nm}$ in the $\mathrm{X}$-direction and $\sim 108 \mathrm{~nm}$ in the Y-direction. The fluorescence mirror unit (U-MF2; Olympus) consisted of a dichroic mirror (T510LPXRXT for Alexa Fluor 488; T585LP for Alexa Fluor 594), an excitation filter (ET480/40x for Alexa Fluor 488; ET560/40x for Alexa Fluor 594), and an 
emission filter (ET535/50m for Alexa Fluor 488; ET630/75m for Alexa Fluor 594), with all filters purchased from Chroma. After acquisition, Huygens Essential (Scientific Volume Imaging) was used to remove noise and reassign out-of-focus light by deconvolution with a theoretical point-spread function (CMLE method). Maximum intensity projections were generated with ImageJ software (NIH) that also enabled adjustment of contrast, brightness, levels, and gamma (over the entire image).

Two-photon fluorescence microscopy and $\mathrm{Ca}^{2+}$ imaging. Red (from Alexa Fluor 594) and green (from OGB-1) fluorescence for structural and functional imaging, respectively, were imaged with the MOM equipped with a computer-controlled, mode-locked, ultrafast-pulsed Ti:sapphire laser (Mai Tai DeepSee, SpectraPhysics) tuned to $810 \mathrm{~nm}$. Scanning was performed by galvanometric scanners (MicroMax 673XX dual axis, Cambridge Technology) and $3 \mathrm{~mm}$ mirrors $(6210 \mathrm{H}$, Cambridge Technology). Epifluorescence was detected by multialkali photomultiplier tubes (R6357; Hamamatsu) and the analog signals were digitized by an acquisition board (NI-6110E; National Instruments). The intensity of the laser light was attenuated and controlled by an electro-optic modulator (350-80LA with BK option; ConOptics) driven by a 302RM amplifier (ConOptics). Two-photon microscopy and image acquisition was controlled by ScanImage software (v3.8.1; Pologruto et al., 2003). Image stacks were acquired as a series of optical slices $(512 \times 512$ or $1024 \times$ 1024 pixels; $2-3$ frames/slice) at focal plane intervals of 0.2 or $0.4 \mu \mathrm{m}$. For imaging intracellular $\mathrm{Ca}^{2+}$ dynamics of A17 varicosities, we sampled fluorescence (OGB-1) from individual varicosities in both line-scan (64 pixels/line, temporal resolution $\sim 960 \mathrm{~Hz})$ and frame-scan mode $(16 \times$ 16 pixels, temporal resolution $\sim 25 \mathrm{~Hz}$ ). $\mathrm{Ca}^{2+}$ imaging started $20-30$ min after establishing the whole-cell configuration to allow for maximal indicator loading at A17 varicosities in stratum 5 (S5) of the IPL. Linescan and frame-scan imaging data were analyzed by custom routines developed under IGOR Pro. Background fluorescence $\left(F_{\mathrm{b}}\right)$ was measured as the average signal from a rectangular area close to the region of interest and baseline fluorescence $\left(F_{0}\right)$ was measured by averaging the signal during a 250-800 ms interval before stimulus onset. For a given signal $(F)$, the relative change in fluorescence related to a change in $\mathrm{Ca}^{2+}$ was calculated as follows (Yasuda et al., 2004):

$$
\frac{\Delta F}{F_{0}}=\frac{F-F_{0}}{F_{0}-F_{b}}
$$

and for simplicity referred to as $\Delta F / F$.

Structural images were deconvolved with Huygens Essential. ImageJ was used to generate maximum intensity projections and to adjust contrast, brightness, levels, and gamma (over the entire image).

Statistical analysis. Data are presented as mean $\pm \operatorname{SEM}(n=$ number of cells or varicosities) with ranges either displayed by individual data points in bar graphs or stated explicitly. Percentages are calculated as percentage of control. Statistical analyses with comparisons between or within groups were performed using Student's two-tailed $t$ test (paired and unpaired as appropriate) or ANOVA. To test for differences among groups, we obtained adjusted $p$ values by Tukey's or Sidak's multiplecomparison procedures for differences within one group (normal or diabetic) and between two groups (normal vs diabetic), respectively. Differences were considered statistically significant at the $p<0.05$ level. The number of individual trials included in the averaged traces in the figures is stated for each case.

\section{Results}

Targeting the RBC-AII-A17 microcircuit in rat retinal slices

The cellular elements and basic synaptic connectivity of the RBCAII-A17 microcircuit are illustrated schematically in Figure 1. Cells were targeted for electrophysiological recording as described in Materials and Methods. Whereas both AII and A17 amacrines receive glutamatergic input from RBCs (Kolb and $\mathrm{Fa}-$ miglietti, 1974; Hartveit, 1999; Singer and Diamond, 2003; Veruki et al., 2003; Chávez et al., 2006), they differ markedly in their morphology (Fig. 1D,E). A17 amacrines are wide-field amacrine cells and receive input from a large number of bipolar cells (Nelson and Kolb, 1985; Grimes et al., 2010). In contrast, AII amacrines are narrow-field amacrine cells with shorter processes and consequently more amenable to high-resolution recording of spEPSCs (Veruki et al., 2003). There were no obvious morphological differences between these three cell types in diabetic compared with normal animals. Animals with diabetes were used for experiments $24 \pm 1 \mathrm{~d}$ (range 18-36) after injection with streptozotocin. For our study, we used a total of 25 normal, 23 diabetic, and three insulin-treated diabetic rats.

\section{Increased frequency of spEPSCs in AII amacrines from diabetic animals}

To probe the dynamics and excitability of the individual microcircuit components, we first recorded glutamatergic spEPSCs mediated by AMPARs in AII amacrines (Veruki et al., 2003) from normal and diabetic animals (Fig. $2 A-C$ ). In normal animals (Fig. 2B), the frequency of spEPSCs was $122 \pm 13 \mathrm{~Hz}$ (Fig. 2D; $n=16$ cells). In contrast, for diabetic animals (Fig. 2C) the frequency was considerably higher at $238 \pm 20 \mathrm{~Hz}$ (Fig. $2 D ; n=14$ cells; $F_{(2,35)}=16.01, p<0.0001$, one-way ANOVA). In diabetic rats successfully treated with insulin to normalize blood glucose levels, the frequency of spEPSCs was $110 \pm 23 \mathrm{~Hz}$ (Fig. $2 D ; n=8$ cells), similar to that in normal animals $\left(F_{(2,35)}=16.01, p=\right.$ 0.937, one-way ANOVA), suggesting that the increased spEPSC frequency was related to development of diabetes and hyperglycemia. We did not observe any amplitude or kinetic differences between spEPSCs in AIIs from normal and diabetic animals (Table 1).

\section{Reduced GABAergic inhibition of presynaptic inputs to AII amacrines from diabetic animals}

The difference in frequency of spEPSCs in AII amacrines from normal and diabetic animals, without a change in amplitude and kinetic parameters, suggests a presynaptic mechanism. AII amacrines receive synaptic inputs from RBCs (Kolb and Famiglietti, 1974) and some types of OFF-cone bipolar cells (Kolb, 1979). Because the input from RBCs is substantial (Strettoi et al., 1992), we focused on the possibility that there could be a change in the release from these cells in diabetic animals. An effect of diabetes on exocytosis could be mediated by a direct effect on RBCs, or alternatively, by reduced inhibitory input resulting in disinhibition. RBCs receive inhibitory input from wide-field GABAergic amacrine cells (both reciprocal and nonreciprocal) and narrowfield glycinergic amacrine cells (Eggers and Lukasiewicz, 2011).

To probe for differences in inhibitory input to the presynaptic inputs to AII amacrines between normal and diabetic animals, we examined the effect of blocking glycinergic and GABAergic neurotransmission. Blocking glycine or $\mathrm{GABA}_{\mathrm{A}}$ receptors $\left(\mathrm{GABA}_{\mathrm{A}^{-}}\right.$ Rs) had no effect on the frequency of spEPSCs in AII amacrines from either normal or diabetic animals (Fig. 2E,F). However, blocking $\mathrm{GABA}_{\mathrm{C}}$ receptors $\left(\mathrm{GABA}_{\mathrm{C}} \mathrm{Rs}\right)$ markedly increased the frequency of spEPSCs in AII amacrines from normal animals $(90 \pm 16 \mathrm{~Hz}$ in control vs $162 \pm 25 \mathrm{~Hz}$ after pharmacological block; $n=4$ cells; $F_{(3,24)}=3.486, p=0.0081$, two-way ANOVA; Fig. $2 E$ ). In contrast, blocking $\mathrm{GABA}_{\mathrm{C}} \mathrm{Rs}$ had no effect on the frequency of spEPSCs in AII amacrines from diabetic animals $(226 \pm 22 \mathrm{~Hz}$ in control vs $226 \pm 19 \mathrm{~Hz}$ after pharmacological block; $n=6$ cells; $F_{(3,24)}=3.486, p>0.999$, two-way ANOVA; Fig. $2 F)$. After blocking $\mathrm{GABA}_{\mathrm{C}} \mathrm{Rs}$, there was no difference in spEPSC frequency between AII amacrines from normal and diabetic animals ( $p=0.111$, two-way ANOVA). These results suggested that baseline inhibition mediated by $\mathrm{GABA}_{\mathrm{C}}$ Rs on bipolar 


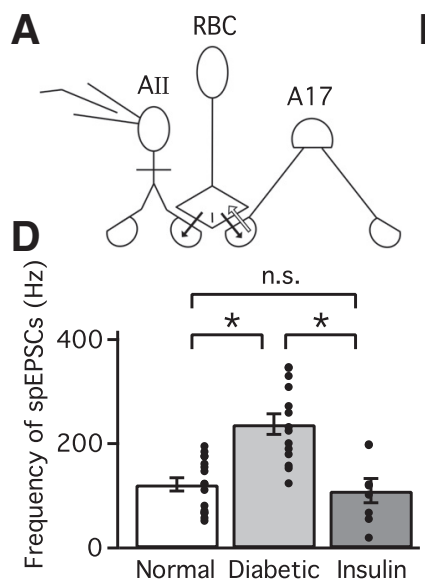

B

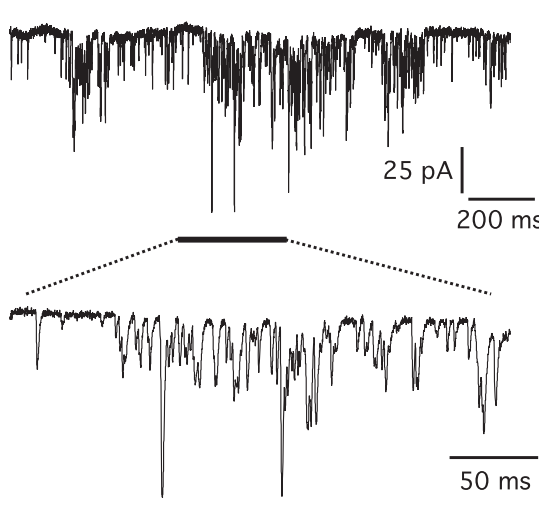

C

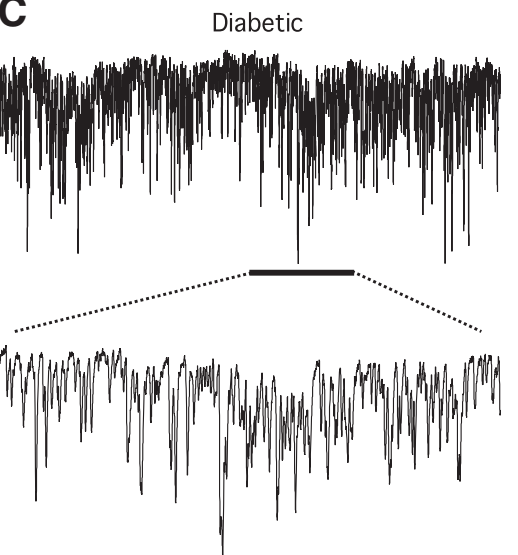

E

$\mathbf{F}$

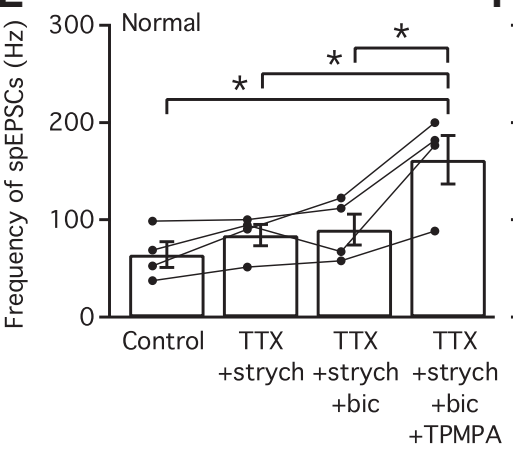

G
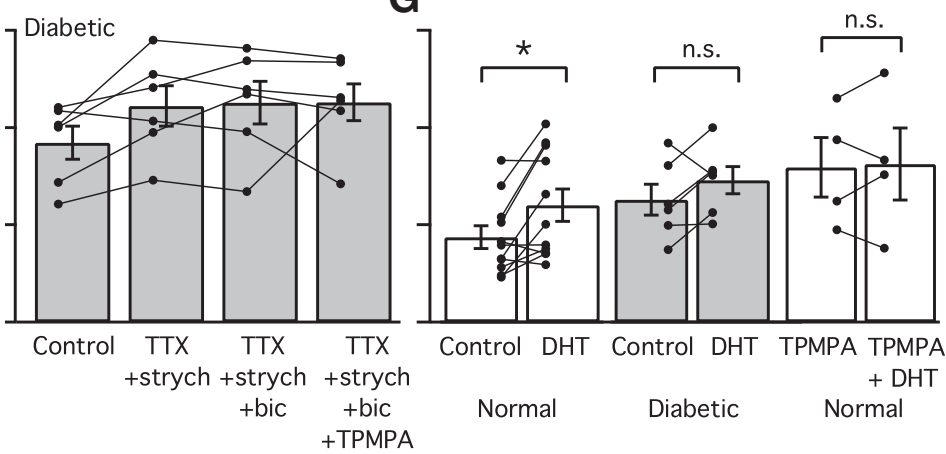

Figure 2. Increased frequency of spEPSCs in All amacrine cells from diabetic animals and involvement of A17 amacrine cells. $A$, Recording location (All) in RBC-All-A17 microcircuit. $\boldsymbol{B}$, spEPSCs (transient inward currents with fast kinetics) in an All amacrine cell from a normal animal. To ensure that spEPSCs were not contaminated by glycine or GABA $A_{A}$ receptor inputs or spontaneous action currents, we performed the recordings in the presence of strychnine, bicuculline, and TTX ( $B, C$. Here and in $C$, activity is displayed at both a slow (top trace) and a fast time scale (bottom trace; solid horizontal line indicates period of top trace expanded in bottom trace). C, spEPSCs in an All amacrine cell from a diabetic animal. Notice higher frequency of spEPSCs compared with $\boldsymbol{B}$. D, Frequency of spEPSCs (here and later, bars represent mean \pm SEM) in All amacrine cells from normal animals (open bar; $n=16$ cells), diabetic animals (light gray bar; $n=14$ cells), and insulin-treated diabetic animals (dark gray bar; $n=8$ cells). Here and later, data from individual recordings are represented by circles and the results from statistical comparisons between averages are indicated by $n$.s. (no significant difference; $p>0.05$ ) and a single asterisk (statistically significant difference; $p<0.05)$. $E$, Frequency of $\operatorname{spEPSCs}(n=4$ cells) in All amacrine cells from normal animals. Here and later, data points for the same cell are connected by lines. Four different recording conditions were tested sequentially: control (no pharmacological blockers added), TTX + strychnine (to block voltage-gated $\mathrm{Na}^{+}$channels and glycine receptors), $T$ TX + strychnine + bicuculline (to also block GABA ${ }_{A}$ receptors), and TTX + strychnine + bicuculline + TPMPA (to also block GABA ${ }_{C}$ receptors). Only comparisons with statistically significant difference indicated. $\boldsymbol{F}$, Frequency of spEPSCs ( $n=6$ cells) in All amacrine cells from diabetic animals. As in $\boldsymbol{E}$, four different recording conditions were

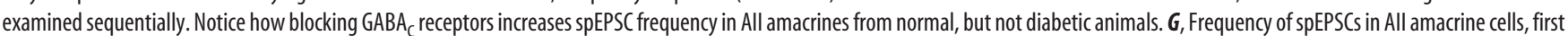
during a control condition (with TTX + strychnine) and then after treatment with the neurotoxin 5,7-DHT to ablate A17 amacrine cells and their reciprocal inhibition of RBCs. Three different groups of cells were tested with 5,7-DHT: normal ( $n=11$ cells), diabetic ( $n=6$ cells), and normal with pharmacologically blocked GABA $c$ receptor-mediated inhibition (TPMPA; $n=4$ cells). Notice how ablating A17 amacrine cells increased the frequency of spEPSCs in All amacrine cells from normal animals, but not from diabetic animals or from normal animals with pharmacologically blocked $\mathrm{GABA}_{c}$ receptor-mediated inhibition.

Table 1. Amplitude and kinetic parameters for spEPSCs in All amacrine cells from normal and diabetic animals

\begin{tabular}{llll}
\hline & Normal $(n=16$ cells) & Diabetic $(n=9$ cells $)$ & $p$ (unpaired $t$ test) \\
\hline Peak amplitude & $18 \pm 1 \mathrm{pA}$ & $21 \pm 1 \mathrm{pA}$ & 0.087 \\
& $(11-28)$ & $(14-27)$ & \\
$10-90 \%$ rise time & $433 \pm 20 \mu \mathrm{s}$ & $407 \pm 11 \mu \mathrm{s}$ & 0.383 \\
& $(299-601)$ & $(351-464)$ & \\
$\tau_{\text {decay }}$ & $1.01 \pm 0.05 \mathrm{~ms}$ & $0.92 \pm 0.03 \mathrm{~ms}$ & 0.192 \\
& $(0.75-1.45)$ & $(0.80-1.12)$ &
\end{tabular}

spEPSCs recorded in the presence of the pharmacological blockers strychnine, bicuculline, and TTX. Data stated as mean \pm SEM (range). Number of events averaged for each cell: $95-1013$. Cells where a sufficient number of well separated events could not be obtained were excluded.

cells presynaptic to AII amacrines is markedly reduced in diabetic animals.

Reduced release of GABA from A17 amacrines in diabetic animals

The reduced tonic activation of $\mathrm{GABA}_{\mathrm{C}}$ Rs on bipolar input to AII amacrines in diabetic animals could be mediated by reduced
$\mathrm{GABA}_{\mathrm{C}} \mathrm{R}$ efficacy or reduced release of GABA. However, RBCs from animals with streptozotocin-induced diabetes display robust $\mathrm{GABA}_{\mathrm{C}} \mathrm{R}$-mediated responses (Ramsey et al., 2006, 2007), suggesting that the first possibility is less likely. $G_{A B A} R s$ on $\mathrm{RBCs}$ are activated by synaptic input from both reciprocal (A17) and nonreciprocal amacrine cells (Hartveit, 1999; Chávez et al., 2006, 2010; Eggers and Lukasiewicz, 2006, 2011). To distinguish between these two inputs we used 5,7-DHT, a neurotoxin that specifically eliminates input to RBCs from reciprocal A17 amacrines (Dong and Hare, 2003; Chávez et al., 2006), but not from nonreciprocal amacrine cells (Chávez et al., 2010). For AII amacrines from normal animals, adding 5,7-DHT to the bath solution resulted in a significant increase of spEPSC frequency (Fig. $2 G ; 87 \pm 12 \mathrm{~Hz}$, control; $120 \pm 16 \mathrm{~Hz}, 5,7-\mathrm{DHT} ; n=11$ cells, $F_{(1,15)}=9.557, p=0.0122$, two-way ANOVA), suggesting that A17 amacrines mediate a baseline GABAergic inhibition of RBC input to AII amacrines. In contrast, for AII amacrines from diabetic animals, there was no difference in spEPSC frequency after adding 5,7-DHT (Fig. 2G; $126 \pm 16 \mathrm{~Hz}$, control; $146 \pm 14 \mathrm{~Hz}$, 
5,7-DHT; $n=6$ cells, $F_{(1,15)}=9.557, p=0.308$, two-way ANOVA), suggesting that GABA release from A17 amacrines is compromised in diabetic animals. Ascorbic acid was added as an antioxidant to all solutions with 5,7-DHT, but had no effect on the frequency of spEPSCs in AII amacrines $(52 \pm 25 \mathrm{~Hz}$, control; $57 \pm 27 \mathrm{~Hz}$, ascorbic acid; $n=4$ cells; $p=0.465$, paired $t$ test; TTX and strychnine were present in both conditions).

When 5,7-DHT was applied after blocking $\mathrm{GABA}_{\mathrm{C}} \mathrm{Rs}$ pharmacologically, there was no change in the frequency of spEPSCs in normal AII amacrines (Fig. 2G; $159 \pm 31$ vs $162 \pm 37 \mathrm{~Hz}$; $n=$ 4 cells, $p=0.822$, paired $t$ test). Correspondingly, the effect of blocking $\mathrm{GABA}_{\mathrm{C}} \mathrm{Rs}$ was occluded by prior treatment with 5,7DHT (101 \pm 24 vs $104 \pm 33 \mathrm{~Hz}, n=4$ cells, $p=0.867$, paired $t$ test). Thus, the increased frequency of spEPSCs in AII amacrines from diabetic animals can be attributed to reduced release of GABA from A17 amacrines.

Reduced activation of $\mathrm{GABA}_{\mathrm{C}}$ Rs on RBCs in diabetic animals Reduced release of GABA from A17 amacrines and reduced activation of $\mathrm{GABA}_{\mathrm{C}} \mathrm{Rs}$ on bipolar cells presynaptic to AII amacrines in diabetic animals suggest that RBCs are inhibited by baseline activation of $\mathrm{GABA}_{\mathrm{C}} \mathrm{Rs}$ in normal animals (similar to goldfish bipolar cells; Hull et al., 2006; Palmer, 2006). To directly examine whether $\mathrm{GABA}_{\mathrm{C}} \mathrm{R}$-mediated inhibition is reduced by diabetes, we recorded from RBCs in normal and diabetic animals (Fig. 3A). To increase the driving force for chloride-mediated currents without cell depolarization (that in itself could perturb the microcircuit dynamics), we recorded with an intracellular solution with high chloride concentration such that the chloride equilibrium potential $\left(E_{\mathrm{Cl}}\right)$ was $\sim 0 \mathrm{mV}\left(V_{\text {hold }}=-60 \mathrm{mV}\right)$. After recording the holding current $\left(I_{\text {hold }}\right)$ continuously for $10 \mathrm{~min}$, we blocked $\mathrm{GABA}_{C}$ Rs pharmacologically. In RBCs from normal animals, this evoked an outward current in all cells tested (Fig. $3 B, D$; average change in $I_{\text {hold }} 5.5 \pm 1.3 \mathrm{pA} ; n=10$ cells; $I_{\text {hold }}$ averaged over $5 \mathrm{~s}$ epochs). In contrast, for RBCs from diabetic animals, blocking $\mathrm{GABA}_{\mathrm{C}} \mathrm{Rs}$ had no effect on $I_{\text {hold }}$ (Fig. $3 C, D$; average change $-0.8 \pm 0.6 \mathrm{pA} ; n=9$ cells; $p=0.0005$, unpaired $t$ test). This supports our hypothesis that diabetes reduces release of GABA from A17 amacrines and thereby reduces the tonic activation of $\mathrm{GABA}_{C}$ Rs on RBCs.

\section{Increased frequency of spEPSCs in A17 amacrines in diabetic animals}

If the increased frequency of glutamatergic spEPSCs in AII amacrines from diabetic animals is predominantly mediated by increased release of glutamate from RBCs, this predicts a similar increase in frequency of spEPSCs in A17 amacrines. Recordings of spEPSCs in A17 amacrines (Fig. 4A) were overall noisier than for AII amacrines (Fig. $4 B, C$ ), presumably reflecting overlapping synaptic input that could not be adequately resolved because of high frequency and electrotonic filtering of bipolar cell inputs spread across the length of thin processes that extend hundreds of $\mu \mathrm{m}$ from the cell body (Nelson and Kolb, 1985; Grimes et al., 2010). Nevertheless, the frequency of spEPSCs was significantly higher in A17 amacrines from diabetic ( $51 \pm 8 \mathrm{~Hz}, n=10$ cells) compared with normal animals $(28 \pm 5 \mathrm{~Hz}, n=10$ cells; $p=$ 0.0336 , unpaired $t$ test; Fig. $4 D$ ). We did not observe any amplitude or kinetic differences between spEPSCs in A17s from normal and diabetic animals (Table 2).
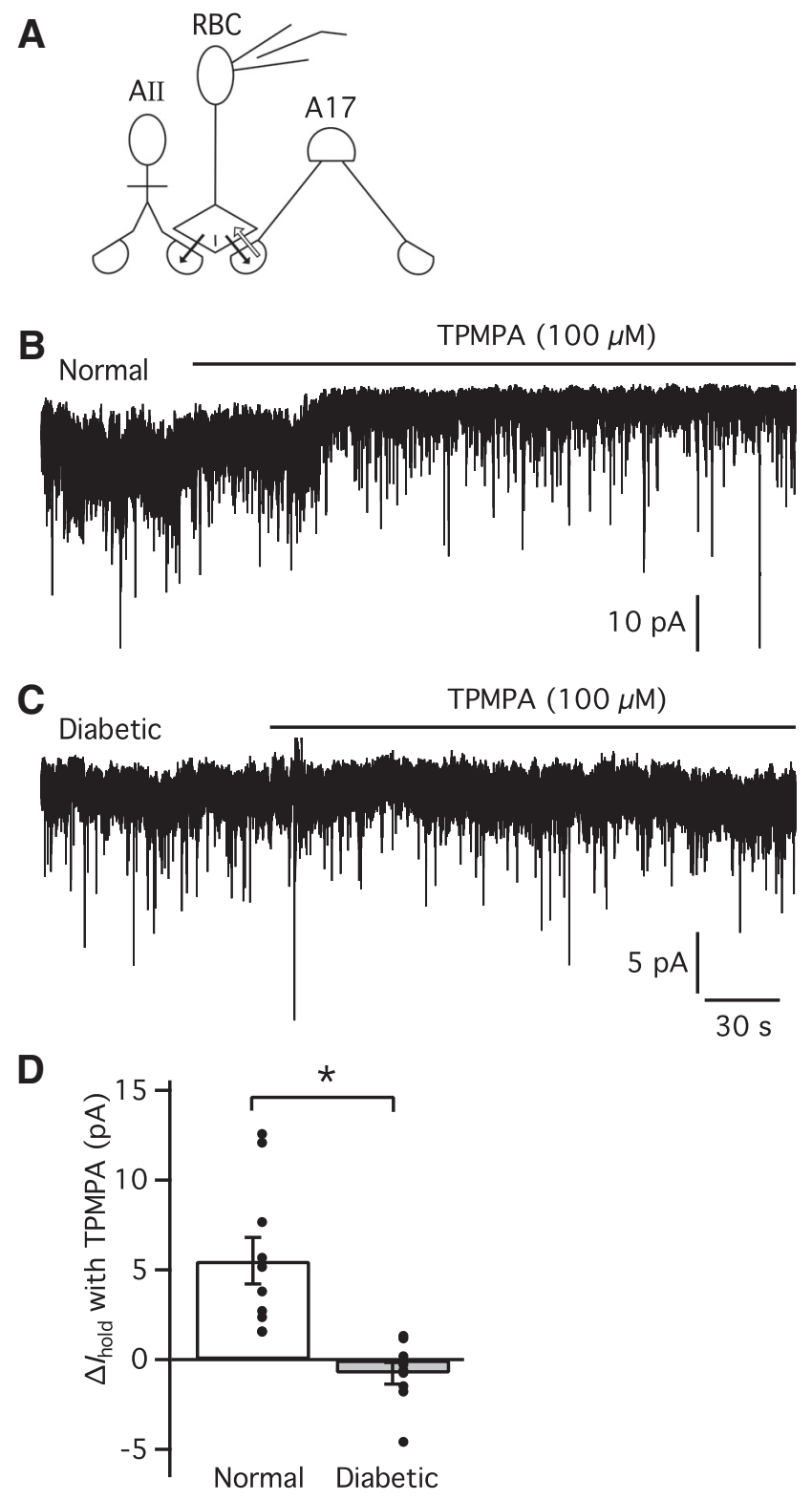

Figure 3. Blocking $G A B A_{C}$ receptor-mediated inhibition evokes an outward current in RBCS from normal, but not from diabetic animals. $A$, Recording location (RBC) in RBC-All-A17 microcircuit. $\boldsymbol{B}$, Continuous voltage-clamp recording of $\mathrm{RBC}$ from normal animal and outward shift of holding current evoked by application of the $\mathrm{GABA}_{C}$ receptor antagonist TPMPA. Here and in $C$, we recorded with symmetrical chloride concentrations $\left(E_{\mathrm{Cl}}=2.7 \mathrm{mV}\right)$ to increase the driving force for chloride $\left(V_{\text {hold }}=-60 \mathrm{mV}\right)$. C, Continuous voltage-clamp recording of $\mathrm{RBC}$ from diabetic animal and no change in holding current evoked by application of TPMPA. D, Average change in holding current $\left(\Delta I_{\text {hold }}\right.$; mean $\left.\pm S E M\right)$ evoked by TPMPA in RBCs from normal (open bar; $n=10$ cells), and diabetic (light gray bar; $n=9$ cells) animals. Positive and negative values correspond to outward and inward currents, respectively.

\section{Diabetes changes the pharmacological properties of spEPSCs in $\mathrm{A} 17$ but not AII amacrines}

The release of GABA from A17 amacrines can be driven by influx of $\mathrm{Ca}^{2+}$ through CP-AMPARs (Chávez et al., 2006). Accordingly, one possible explanation for reduced release of GABA in diabetic animals is a change in AMPAR subunit composition that reduces $\mathrm{Ca}^{2+}$ permeability. A change in subunit composition could be accompanied by differences in pharmacological properties (Traynelis et al., 2010). To investigate this, we examined the effect of IEM 1460 on spEPSCs in normal and diabetic animals. IEM 
A

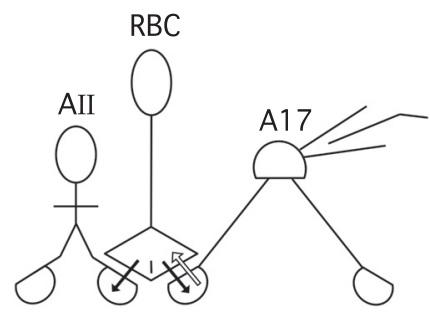

B

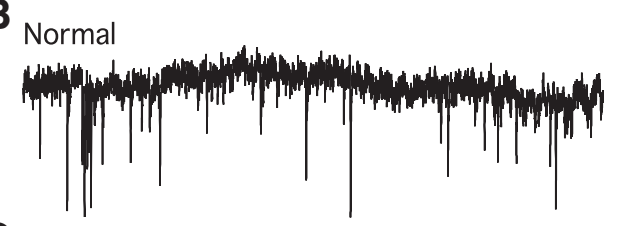

C

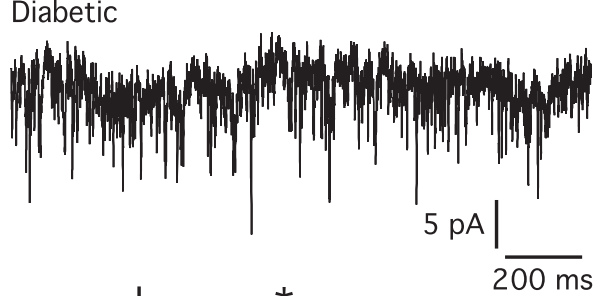

D

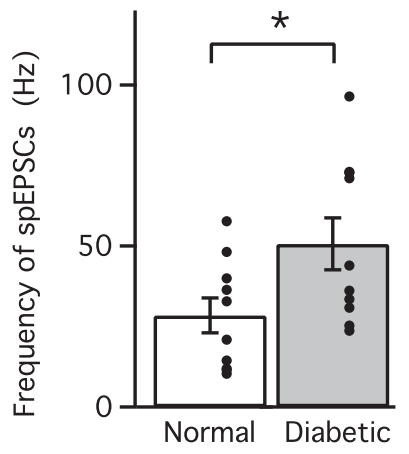

Figure 4. Frequency of spEPSCs in A17 amacrine cells is higher in diabetic than normal animals. $A$, Recording location (A17) in RBC-All-A17 microcircuit. B, spEPSCs in an A17 amacrine cell from a normal animal. $C$, spEPSCs in an A17 amacrine cell from a diabetic animal. Notice higher frequency of spEPSCs compared with $\boldsymbol{B}$. D. Frequency of spEPSCs in A17 amacrine cells from normal (open bar; $n=10$ cells) and diabetic (light gray bar; $n=10$ cells) animals.

Table 2. Amplitude and kinetic parameters for spEPSCs in A17 amacrine cells from normal and diabetic animals

\begin{tabular}{lcll}
\hline & Normal $(n=10$ cells $)$ & Diabetic $(n=10$ cells $)$ & $p$ (unpaired $t$ test) \\
\hline Peak amplitude & $5.2 \pm 0.4 \mathrm{pA}$ & $5.4 \pm 0.3 \mathrm{pA}$ & 0.620 \\
& $(3.4-6.7)$ & $(3.7-6.9)$ & \\
$10-90 \%$ rise time & $562 \pm 26 \mu \mathrm{s}$ & $548 \pm 25 \mu \mathrm{s}$ & 0.709 \\
& $(471-730)$ & $(452-668)$ & \\
$\tau_{\text {decay }}$ & $1.66 \pm 0.15 \mathrm{~ms}$ & $1.54 \pm 0.04 \mathrm{~ms}$ & 0.433 \\
& $(1.07-2.41)$ & $(1.31-1.66)$ & \\
\hline
\end{tabular}

spEPSCs recorded in the presence of the pharmacological blockers strychnine, bicuculline, TPMPA, and TTX. Data stated as mean \pm SEM (range). Number of events averaged for each cell: $483-1361$.

1460 is a voltage-dependent open-channel blocker of AMPARs with a lower $\mathrm{IC}_{50}$ for GluA2-lacking receptors than for GluA2containing receptors (Magazanik et al., 1997; Buldakova et al., 1999). For spEPSCs in A17 amacrines, IEM 1460 reduced the amplitude in both normal and diabetic animals, but spEPSCs in diabetic animals were more resistant to IEM 1460 than spEPSCs in normal animals. This is illustrated by the examples in Figure $5 A$ of average spEPSCs in A17 amacrines from a normal (left) and a diabetic animal (right). On average, the IEM-resistant current in diabetic animals was $56 \pm 6 \%(n=4$ cells $)$ of the correspond- ing control value, significantly larger than in normal animals $(39 \pm 1 \%, n=5$ cells; $p=0.0128$, unpaired $t$ test; Fig. $5 B)$.

In contrast, for AII amacrines, IEM 1460 reduced the amplitude of spEPSCs equally in normal and diabetic animals (Fig. $5 C, D)$. On average, the IEM-resistant current in AII amacrines from diabetic animals was $54 \pm 8 \%(n=4$ cells $)$ of the corresponding control value and in AII amacrines from normal animals it was $59 \pm 4 \%$ ( $n=5$ cells; $p=0.592$, unpaired $t$ test; Fig. $5 D$ ). This suggested that diabetes induced a change in the subunit composition of synaptic AMPARs in A17, but not AII amacrines.

\section{Diabetes reduces the single-channel conductance of synaptic} AMPARs in A17 but not in AII amacrines

A change in the subunit composition that decreases the $\mathrm{Ca}^{2+}$ permeability of the AMPARs is likely to be accompanied by a reduction of the single-channel conductance (Swanson et al., 1997). Due to fast ion channel kinetics and electrotonic filtering, it is not possible to estimate the single-channel conductance of synaptic AMPARs by directly resolving channel openings in the decay phase of spEPSCs, but nonstationary noise analysis can be a valuable tool for investigating changes in synaptic properties related to development, plasticity, and disease processes (Hartveit and Veruki, 2007). Thus, although the accuracy of the obtained single-channel conductance might be limited, a comparison between conditions, with all other factors being constant, can provide valuable mechanistic information.

Peak-scaled nonstationary noise analysis of spEPSCs recorded in A17 amacrines revealed that the single-channel conductance was lower in cells from diabetic animals (Fig. $5 E, F$ ). For A17 amacrines from diabetic animals, the average was $8.6 \pm 0.8 \mathrm{pS}$ $(n=5$ cells; Fig. $5 G$ ), significantly lower than for A17 amacrines from normal animals $(12.6 \pm 0.4 \mathrm{pS}, n=5$ cells; $p=0.0015$, unpaired $t$ test; Fig. $5 G$ ). Because the peak scaling yielded skewed, as opposed to parabolic, variance versus mean curves (Hartveit and Veruki, 2007), we repeated the analysis without peak scaling. In this case, the variance versus mean curves deviated strongly upward (Fig. 5E,F), but the initial slope of the curves corresponds to the unitary current amplitude (Hartveit and Veruki, 2007) and gave very similar results to the analysis with peak scaling. In contrast to A17 amacrines, for the AII amacrines there was no difference in the single-channel conductance for spEPSCs in cells from normal $(16.9 \pm 1.7 \mathrm{pS}, n=6$ cells; Fig. $5 H)$ and diabetic animals ( $20.8 \pm 3.8 \mathrm{pS}, n=4$ cells; $p=0.321$, unpaired $t$ test; Fig. $5 H)$.

\section{Diabetes reduces glutamate-evoked $\mathrm{Ca}^{2+}$ influx through AMPARs on A17 varicosities}

The observed changes of pharmacological properties and singlechannel conductance of AMPARs of A17 amacrines in diabetic animals suggest, but do not by themselves demonstrate reduced $\mathrm{Ca}^{2+}$ permeability. To directly investigate this, we combined microiontophoretic application of glutamate and two-photon $\mathrm{Ca}^{2+}$ imaging of A17 varicosities (Grimes et al., 2009; Fig. 6A). Twophoton microscopy allowed targeting of fine-tipped pipettes (filled with $150 \mathrm{~mm}$ glutamate) to individual varicosities (Fig. $6 B, C)$. When the pipette tip was in close apposition to a varicosity, application of brief $(0.6-1 \mathrm{~ms})$ pulses of glutamate evoked transient inward currents (Fig. $6 D, E$ ). In the varicosity illustrated in Figure $6 B$, the glutamate-evoked current was accompanied by an increase in $\mathrm{Ca}^{2+}$, measured as an increase in the relative fluorescence of OGB-1 $(\Delta F / F$; Fig. $6 D)$. For five A17 varicosities (from 2 cells) from normal animals, the average peak inward current was $16.4 \pm 4.3 \mathrm{pA}$ (Fig. $6 F$ ) and the average maximum 
A

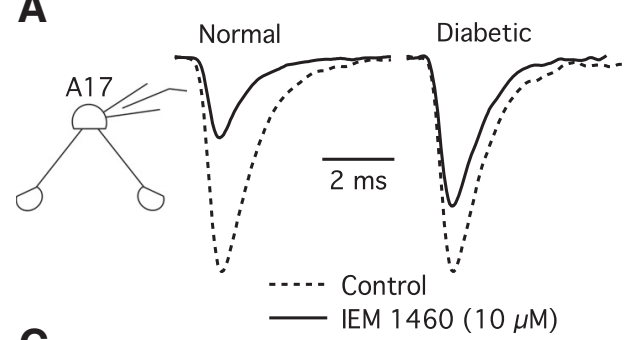

C

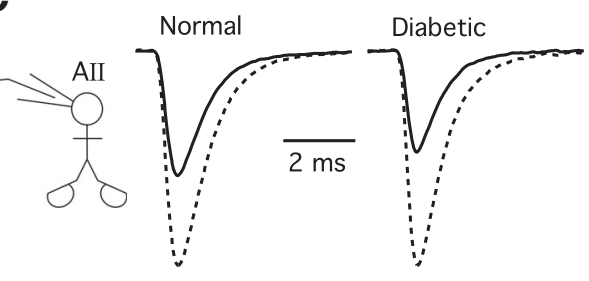

$\mathbf{E}$

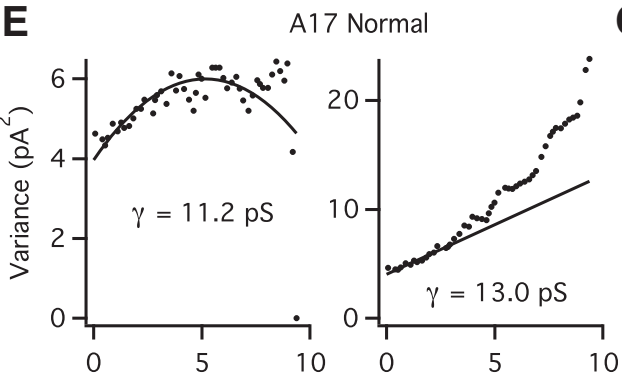

$\mathbf{F}$

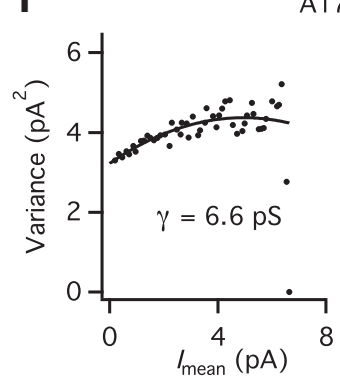

A17 Diabetic

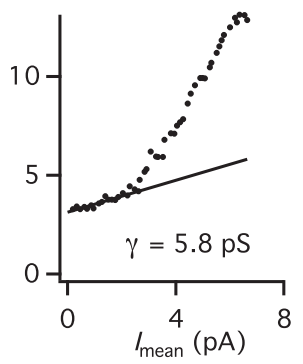

B

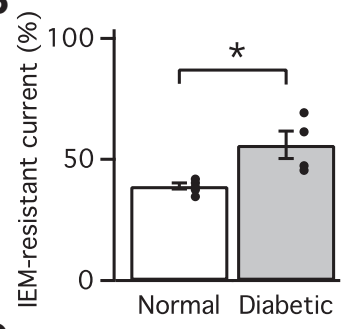

D

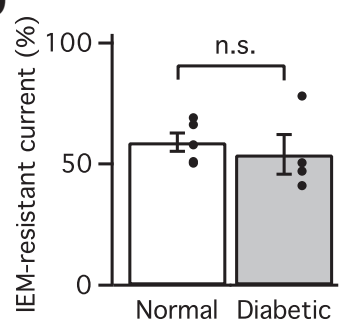

G

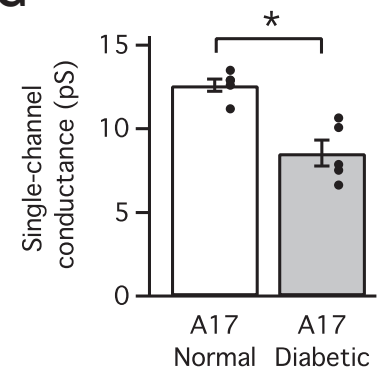

H

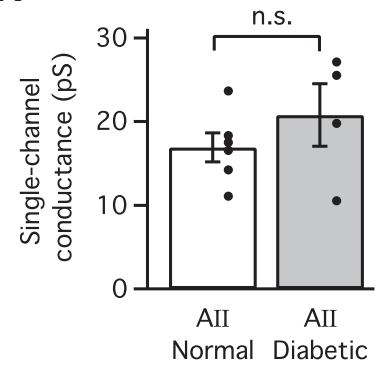

Figure 5. Altered pharmacological and biophysical properties of spEPSCs from A17, but not All amacrine cells in diabetic animals. $A$, Average spEPSCs recorded from two A17 amacrine cells (inset), one from a normal animal (left), in control condition (dashed line; $n=266$ events) and in the presence of the open-channel AMPA receptor blocker IEM 1460 (continuous line; $n=252$ events) and one from a diabetic animal (right), in control condition (dashed line; $n=106$ events) and in the presence of IEM 1460 (continuous line; $n=67$ events). Amplitudes of spEPSC waveforms have been normalized relative to the control waveform and only well separated events were included in the illustrated averages $(\boldsymbol{A}, \boldsymbol{C})$. Notice the smaller suppression by IEM 1460 in the diabetic animal. $\boldsymbol{B}$, Proportion of average spEPSC peak amplitude resistant to IEM 1460 in A17 amacrine cells from normal ( $n=5$ cells) and diabetic ( $n=4$ cells) animals. Notice larger fraction of IEM 1460-resistant current in cells from diabetic animals. $C$, Average spEPSCs recorded from two All amacrine cells (inset), one from a normal animal (left), in control condition (dashed line; $n=366$ events) and in the presence of IEM 1460 (continuous line; $n=222$ events), and one from a diabetic animal (right), in control condition (dashed line; $n=214$ events) and in the presence of IEM 1460 (continuous line; $n=143$ events). Notice similar suppression by IEM 1460 in the normal and diabetic animals. D, Proportion of average spEPSC peak amplitude resistant to IEM 1460 in All amacrine cells from normal ( $n=5$ cells) and diabetic ( $n=4$ cells) animals. No statistically significant difference between cells from normal and diabetic animals with respect to degree of block by IEM 1460. E, Plots of ensemble current variance versus mean current for 348 spEPS(s recorded in an A17 amacrine cell from a normal animal, calculated with (left) or without (right) peak-scaling (see Materials and Methods). Here and in $\boldsymbol{F}$, the data points have been fitted with Eq. 2 (left) or a straight line (right; data points corresponding to the initial slope used for fitting). $\boldsymbol{F}$, Plots of ensemble current variance versus mean current for 545 spEPSCs recorded in an A17 amacrine cell from a diabetic animal, calculated with (left) or without (right) peak-scaling. G, Average single-channel conductance estimated by nonstationary noise analysis of spEPSCs in A17 amacrine cells from normal ( $n=5$ cells) and diabetic ( $n=5$ cells) animals. Notice lower single-channel conductance in diabetic animals. $\boldsymbol{H}$, Average single-channel conductance estimated by nonstationary noise analysis of spEPSCs in All amacrine cells from normal ( $n=6$ cells) and diabetic ( $n=4$ cells) animals. Notice similar single-channel conductance for cells from normal and diabetic animals.

increase of $\mathrm{Ca}^{2+}$ was $65 \pm 19 \%$ (Fig. $6 G$ ). In contrast, when similar experiments were performed with A17 varicosities from diabetic animals, four of six varicosities (from 4 cells) displayed $\mathrm{Ca}^{2+}$ signals $<10 \%$ (Fig. $6 E$ ), with an average maximum increase of $10 \pm 2 \%$ (Fig. $6 G$ ), significantly smaller than for normal varicosities ( $p=0.0111$, unpaired $t$ test). This strongly suggests decreased $\mathrm{Ca}^{2+}$ permeability of AMPARs in A17 amacrines from diabetic animals. All six A17 varicosities displayed an inward current in response to glutamate $(8.8 \pm 1.5 \mathrm{pA})$, not significantly different from varicosities from normal animals $(p=0.107$, unpaired $t$ test; Fig. $6 F)$.

To ensure that the small $\mathrm{Ca}^{2+}$ responses in $\mathrm{A} 17$ varicosities from diabetic animals were not explained by baseline saturation of OGB-1, we examined the response to depolarizing voltage steps (from $V_{\text {hold }}$ to $0 \mathrm{mV}$; cf. Grimes et al., 2009). In eight of nine A17 varicosities from diabetic animals there was a clear $\mathrm{Ca}^{2+}$ signal $(120 \pm 27 \% ; n=8$ varicosities from 5 cells), strongly suggesting that there was not a problem with indicator dye saturation in diabetic animals. The presence of $\mathrm{Ca}^{2+}$ responses mediated via depolarizing voltage steps and activation of voltagegated $\mathrm{Ca}^{2+}$ channels (Grimes et al., 2009) also suggests that putative $\mathrm{Ca}^{2+}$ signals mediated by direct depolarization of A17 varicosities by the microiontophoretic pipette were not a problem, given the small $\mathrm{Ca}^{2+}$ responses evoked by microiontophoretic application of glutamate in the diabetic animals.

There were no obvious morphological differences between A17 varicosities in diabetic compared with normal animals. It is difficult to exclude the possibility that such changes could occur, however, especially with diabetes of longer duration than in our study. Further investigations of these questions will require highresolution structural imaging in slices or in whole-mounts.

\section{Discussion}

An understanding of the early dysfunction of the neural retina that precedes the microvascular pathology characteristic of later stages of diabetic retinopathy has been hampered by the lack of appropriate cellular models in which to identify specific functional changes at the molecular and cellular level. Differences in methodologies and experimental models have precluded consistent interpretation and leave open the identity of specific retinal neurons and circuits that might be com- 

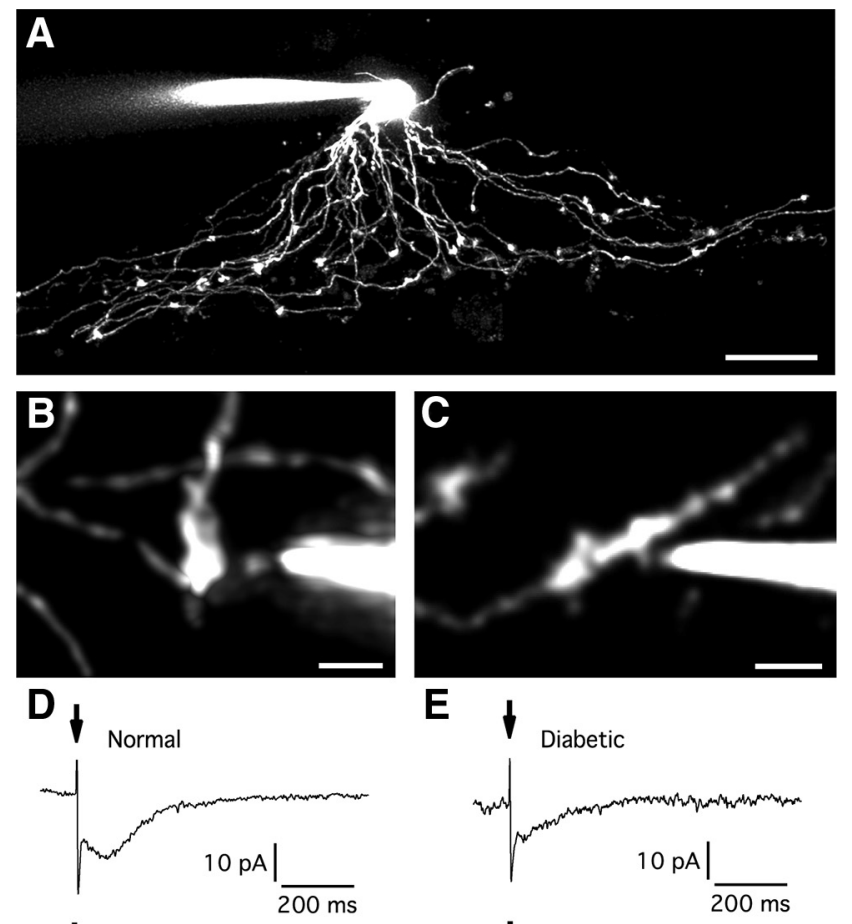

E
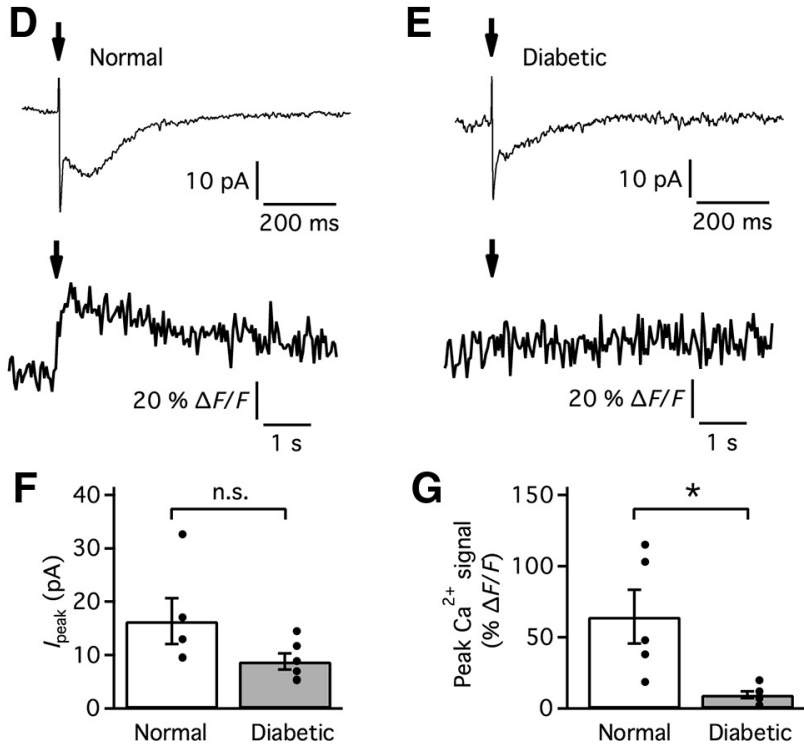

Figure 6. Reduced $\mathrm{Ca}^{2+}$ influx through non-NMDA receptors on A17 amacrine cell varicosities in diabetic animals. A, A17 amacrine cell filled with Alexa Fluor 594 via patch pipette. Maximum intensity projection (along $z$-axis) generated from two-photon fluorescence image stack after deconvolution $(\boldsymbol{A}-\boldsymbol{C})$. Scale bar, $20 \mu \mathrm{m}$. $\boldsymbol{B}$, $\boldsymbol{C}$, Varicosities from two A17 amacrine cells ( $\boldsymbol{B}$, normal, maximum intensity projection of image stack; $\boldsymbol{C}$, diabetic, single focal plane) filled with Alexa Fluor 594 and the $\mathrm{Ca}^{2+}$ indicator dye Oregon Green 488 BAPTA- 1 and targeted by fine-tipped pipettes (right) filled with glutamate and Alexa Fluor 594. Scale bars, $2 \mu \mathrm{m}$. D, Current (top) and $\mathrm{Ca}^{2+}$ (bottom) signals in response to brief microiontophoretic pulses of glutamate ( $-400 \mathrm{nA}$ for $1 \mathrm{~ms}$; vertical arrows) applied to varicosity in $\boldsymbol{B}$ (from normal animal). NMDA receptors blocked by CPP added to the extracellular solution $(\boldsymbol{D}, \boldsymbol{E})$. Each trace, average of five trials $(\boldsymbol{D}, \boldsymbol{E})$. $\boldsymbol{E}$, Current (top) and $\mathrm{Ca}^{2+}$ (bottom) signals in response to brief microiontophoretic pulses of glutamate ( $-600 \mathrm{nA}$ for $1 \mathrm{~ms}$; vertical arrows) applied to varicosity in $\boldsymbol{C}$ (from diabetic animal). $\boldsymbol{F}, \boldsymbol{G}$, Peak amplitude of current $(\boldsymbol{F})$ and $\mathrm{Ca}^{2+}$ signals $(\boldsymbol{G})$ in response to brief microiontophoretic pulses of glutamate to varicosities from A17 amacrines in normal ( $n=5$ varicosities) and diabetic animals ( $n=6$ varicosities).

promised in early diabetes. The RBC-AII-A17 microcircuit is structurally and functionally well characterized, plays a crucial role in visual processing (Diamond and Grimes, 2014), and all three of the constituent cell types are readily accessible and identifiable in the retinal slice preparation (Fig. 1). Whereas AII amacrines convey signals to ON- and OFF-cone bipolar cells via electrical and chemical synapses (for review, see Hartveit and Veruki, 2012), the only output of the A17 amacrine is back onto the RBCs from which it received excitatory inputs (Nelson and Kolb, 1985). Thus, this microcircuit, along with increasing in- sight into its biophysical operational characteristics (Grimes et al., 2009, 2010), provides a unique model in which to investigate functional consequences of diabetes-evoked changes in signaling molecules of retinal neural circuitry.

By probing the functional state and dynamics of the individual microcircuit elements via electrophysiological recording of glutamatergic spEPSCs and two-photon imaging of glutamateevoked $\mathrm{Ca}^{2+}$ signals, we have provided strong evidence for reduced $\mathrm{Ca}^{2+}$ permeability of non-NMDA receptors on A17 amacrines in diabetic animals. As $\mathrm{Ca}^{2+}$ influx via CP-AMPARs can mediate release of GABA from these cells (Chávez et al., 2006), the reduced $\mathrm{Ca}^{2+}$ permeability in diabetic animals leads to disinhibition of RBCs via reduced tonic activation of $\mathrm{GABA}_{\mathrm{C}} \mathrm{Rs}$. The result is an increased release of glutamate from RBCs in diabetic rats (Fig. 7).

\section{Circuit elements involved in the increased glutamatergic} input to AII and A17 amacrine cells

We interpret the increased frequency of spEPSCs in AII amacrines as reflecting increased glutamate release from RBCs. This does not exclude input from OFF-cone bipolar cells which can be presynaptic at the lobular appendages of AII amacrines (for review, see Demb and Singer, 2012), but two findings suggest that input from RBCs makes a significant contribution. First, increased frequency of spEPSCs was also detected in A17 amacrines and these cells are thought to receive the majority, potentially all, of their glutamatergic input from RBCs (Nelson and Kolb, 1985). Second, the neurotoxin 5,7-DHT substantially decreases or eliminates output from A17 amacrines (Chávez et al., 2006), which seem to exclusively direct their output to rod, as opposed to cone, bipolar cells (Nelson and Kolb, 1985), while leaving lateral (nonreciprocal) inhibitory mechanisms intact (Chávez et al., 2010). Accordingly, when 5,7-DHT evokes an increase in spEPSCs in AII amacrines in normal, but not in diabetic animals, this strongly suggests increased glutamate release from RBCs.

An alternative explanation for enhanced glutamate release from RBCs in diabetic animals is reduced sensitivity of GABARs on these cells. However, recordings from acutely isolated RBCs indicate that diabetes increases the sensitivity of $\mathrm{GABA}_{\mathrm{C}} \mathrm{Rs}$ on these cells (Ramsey et al., 2006, 2007), and our results suggest that this increased sensitivity could reflect homeostatic synaptic plasticity and compensation for reduced release of GABA from A17 amacrines.

\section{Plasticity of CP-AMPARs in the RBC-AII-A17 microcircuit}

There is evidence for expression of CP-AMPARs by both A17 and AII amacrines. For A17s, the feedback inhibition triggered by depolarization-evoked glutamate release from RBCs can be suppressed by antagonists that are selective for CP-AMPARs (Chávez et al., 2006) and glutamate release from RBCs evokes postsynaptic $\mathrm{Ca}^{2+}$-influx in A17 varicosities through non-NMDA receptors (Grimes et al., 2009). For AII amacrine cells, there is evidence for somatic extrasynaptic AMPARs with relatively high $\mathrm{Ca}^{2+}$ permeability (Mørkve et al., 2002), agonist-evoked uptake of $\mathrm{Co}^{2+}$ through non-NMDA receptors (Osswald et al., 2007) and inward rectification of the $I-V$ relationship for synaptic currents mediated by RBCs (Singer and Diamond, 2003).

There is strong evidence for activity-dependent regulation of CP-AMPARs in a number of different CNS synapses, with the parallel fiber input to stellate cells in the cerebellar cortex as the best studied case (Cull-Candy et al., 2006). Increased afferent activity increases the proportion of GluA2 subunits in synaptic 


\section{Normal retina}

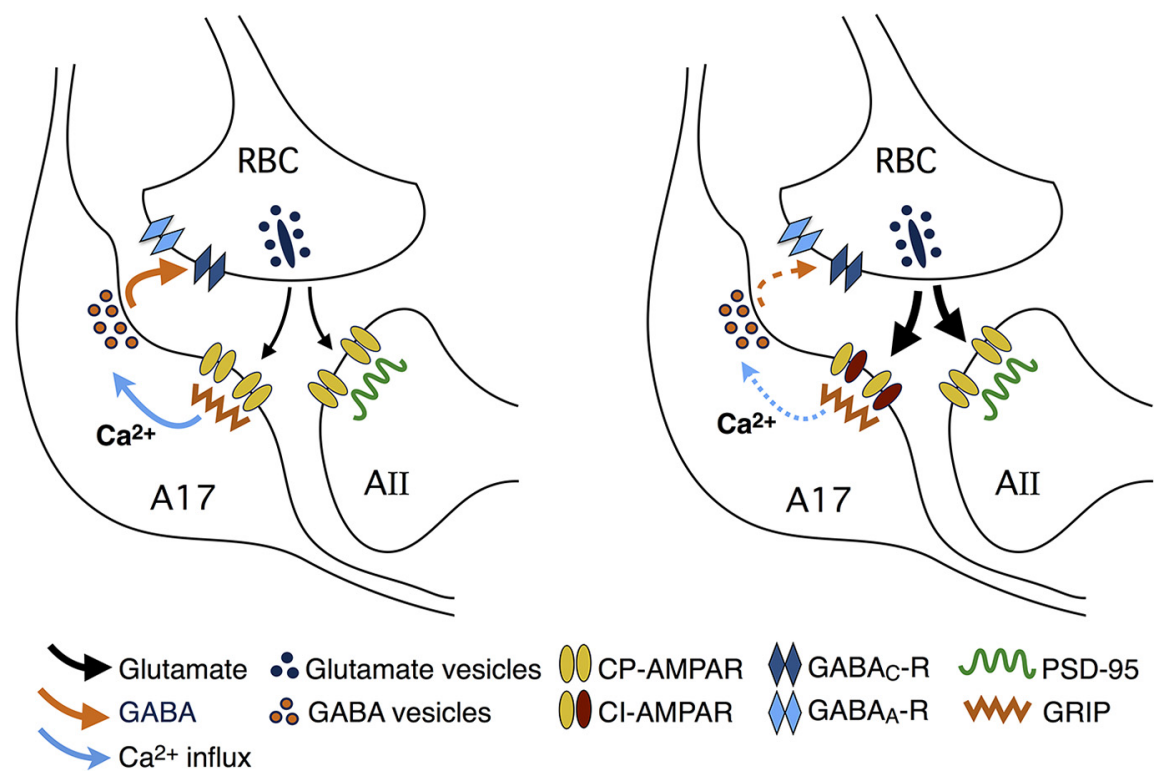

Figure 7. Changes in the RBC-All-A17 microcircuit in early diabetes. Left, The microcircuit under normal conditions, where glutamate released from the RBC acts on $\mathrm{Ca}^{2+}$-permeable AMPARs (CP-AMPARs) on the $\mathrm{A} 17$ and All amacrines. $\mathrm{Ca}^{2+}$ influx leads to the release of GABA from the $A 17$ and subsequent inhibitory feedback to the RBC. Right, The microcircuit in diabetes, with modified dynamics, such that reduced $\mathrm{Ca}^{2+}$ permeability of the AMPARs on the A17 results in decreased release of GABA, reduced inhibitory feedback and increased release of glutamate from the RBC (CI-AMPARs $=\mathrm{Ca}^{2+}$-impermeable AMPARs).

\section{Which mechanisms lead to abnormal regulation of receptors and circuit dynamics?}

Previous work has suggested that high glucose, both in vitro and in vivo, alters the protein levels of specific types of glutamate receptor subunits in retinal neurons. Exposure of retinal cell cultures to elevated concentrations of glucose increases the expression of the GluA2 subunit (Santiago et al., 2006) and there is evidence for an increase of the GluA2 subunit in retinas of diabetic rats and humans (Santiago et al., 2008; Semkova et al., 2010). The changes we observed by electrophysiological recordings from RBCs and AII and A17 amacrine cells are consistent with and can be explained by increased content of GluA2 in synaptic receptors of A17 amacrines. In the recordings of spEPSCs from A17 amacrines, this was detected as a reduction of the apparent single-channel conductance and a decreased sensitivity to the pharmacological blocker IEM 1460, suggesting increased content of GluA2 and predicting reduced $\mathrm{Ca}^{2+}$ permeability. However, there are no obvious candidates among the many biochemical processes thought to be affected by dia-

receptors, expressed as reduced rectification of the $I-V$ relationship and presumably reduced $\mathrm{Ca}^{2+}$ permeability. Reduced afferent activity leads to the opposite effect, with a decreased proportion of GluA2 and increased rectification. If a similar mechanism is operative in the synapse between RBCs and A17 amacrines, it could amplify any perturbation of the normal homeostasis. Regardless of whether the primary disturbance involves the CPAMPARs of A17 amacrines or the exocytotic machinery of RBCs, decreased release of GABA from the A17 amacrines could trigger a positive feedback mechanism where disinhibition and increased glutamate release from RBCs leads to reduced $\mathrm{Ca}^{2+}$ permeability and reduced GABA release from the A17s.

Plasticity at glutamatergic synapses in both physiological and pathological conditions is, at least partly, mediated by dynamic membrane trafficking of AMPARs, with cytoskeletal structures in the postsynaptic density (PSD) playing a role (Hanley, 2014). Several studies have demonstrated a differential distribution of PSD proteins at the RBC to A17-AII dyad synapse (Koulen et al., 1998a, b; Ghosh et al., 2001; Brandstätter et al., 2004), with PSD-95 localizing to the AII amacrine cell and glutamate receptor-interacting protein (GRIP) localizing to the A17 amacrine (Ghosh et al., 2001; Fig. 7). Our results suggest that the AMPARs on A17 amacrines are altered in early diabetes, whereas those on AII amacrines are not and the differential distribution of PSD proteins on these two cells could play a determining role. In particular, GRIP has been implicated in control of $\mathrm{Ca}^{2+}$ permeability of AMPARs at cerebellar synapses (Liu and Cull-Candy, 2005) and could potentially play a similar role at retinal synapses. It will be important to see whether the proposed diabetes-evoked changes of synaptic glutamate receptors and PSD proteins can be verified by immunoelectron microscopy that has the potential to examine the protein expression at the ultrastructural level in all elements of the RBC-AII-A17 microcircuit. betic hyperglycemia (Antonetti et al., 2012; Simó and Hernández, 2014) for directly evoking a change in subunit composition of glutamate receptors. Alternatively, a change in subunit composition could be mediated by normal mechanisms of plasticity in response to perturbed release of glutamate resulting from disturbances in presynaptic $\mathrm{Ca}^{2+}$ dynamics and homeostasis (for review, see Verkhratsky and Fernyhough, 2008). The ability of insulin to counteract the effects evoked by streptozotocin argues against a direct effect of streptozotocin on the neural retina, which suggests instead that hyperglycemia plays a causative role. Nevertheless, it has to be considered that the changes in synaptic transmission and circuit dynamics could be directly related to a lack of insulin, as retinal tissue, similar to other areas of the CNS, is directly sensitive to insulin (Reiter and Gardner, 2003).

\section{Can the observed changes at the level of the RBC-AII-A17 microcircuit explain visual disturbances observed in early diabetic retinopathy?}

The primary importance of the present results is threefold. First, our results indicate that diabetes-evoked changes in glutamate receptor subunit composition can be localized to specific synapses in the intact retina. Similar changes could occur in synapses and microcircuits elsewhere in the retina and CNS in response to early diabetes. Second, the observed changes occur at a very early time point, earlier than several other functional changes that have been reported in the retina. Finally, our results demonstrate changes in synaptic transmission and circuit dynamics that are likely to translate to altered signal processing. Early signs of diabetic retinopathy, before microvascular pathology, include reduced contrast sensitivity and color vision abnormalities (Daley et al., 1987; Lopes de Faria et al., 2001; Reis et al., 2014), which are difficult to relate to specific retinal microcircuits. However, both clinical and experimental studies have found evidence for changes in electroretinogram (ERG) oscillatory potentials (Sakai 
et al., 1995; Hancock and Kraft, 2004; Bearse et al., 2006), which point to changes in inner retina signal processing and potentially an involvement of A17 amacrines. There is evidence that these ERG abnormalities are most prominent and consistent under scotopic conditions, suggesting a higher susceptibility of rod pathways (Aung et al., 2013; Pardue et al., 2014). Specifically, reduced activation of $\mathrm{GABA}_{\mathrm{C}} \mathrm{Rs}$ at $\mathrm{RBC}$ axon terminals could result in reduced dynamic range of scotopic visual responses (Dong and Hare, 2003; Herrmann et al., 2011) and reduced visual sensitivity (Diamond and Grimes, 2014). In a wider perspective, the current results underscore the importance of bridging the gap between specific molecular pathologies and the resulting functional consequences at the levels of microcircuits, networks, and global function.

\section{References}

Antonetti DA, Klein R, Gardner TW (2012) Diabetic retinopathy. N Engl J Med 366:1227-1239. CrossRef Medline

Aung MH, Kim MK, Olson DE, Thule PM, Pardue MT (2013) Early visual deficits in streptozotocin-induced diabetic Long Evans rats. Invest Ophthalmol Vis Sci 54:1370-1377. CrossRef Medline

Bearse MA Jr, Adams AJ, Han Y, Schneck ME, Ng J, Bronson-Castain K, Barez S (2006) A multifocal electroretinogram model for predicting the development of diabetic retinopathy. Prog Retin Eye Res 25:425-448. CrossRef Medline

Bowie D (2012) Redefining the classification of AMPA-selective ionotropic glutamate receptors. J Physiol 590:49-61. CrossRef Medline

Brandstätter JH, Dick O, Boeckers TM (2004) The postsynaptic scaffold proteins ProSAP1/Shank2 and Homer1 are associated with glutamate receptor complexes at rat retinal synapses. J Comp Neurol 475:551-563. CrossRef Medline

Buldakova SL, Vorobjev VS, Sharonova IN, Samoilova MV, Magazanik LG (1999) Characterization of AMPA receptor populations in rat brain cells by the use of subunit-specific open channel blocking drug, IEM-1460. Brain Res 846:52-58. CrossRef Medline

Castilho AF, Liberal JT, Baptista FI, Gaspar JM, Carvalho AL, Ambrósio AF (2012) Elevated glucose concentration changes the content and cellular localization of AMPA receptors in the retina but not in the hippocampus. Neuroscience 219:23-32. CrossRef Medline

Chávez AE, Singer JH, Diamond JS (2006) Fast neurotransmitter release triggered by Ca influx through AMPA-type glutamate receptors. Nature 443:705-708. CrossRef Medline

Chávez AE, Grimes WN, Diamond JS (2010) Mechanisms underlying lateral GABAergic feedback onto rod bipolar cells in rat retina. J Neurosci 30:2330-2339. CrossRef Medline

Cull-Candy S, Kelly L, Farrant M (2006) Regulation of $\mathrm{Ca}^{2+}$-permeable AMPA receptors: synaptic plasticity and beyond. Curr Op Neurobiol 16: 288-297. CrossRef Medline

Daley ML, Watzke RC, Riddle MC (1987) Early loss of blue-sensitive color vision in patients with type I diabetes. Diabetes Care 10:777-781. CrossRef Medline

Demb JB, Singer JH (2012) Intrinsic properties and functional circuitry of the AII amacrine cell. Vis Neurosci 29:51-60. CrossRef Medline

Diamond JS (2011) Calcium-permeable AMPA receptors in the retina. Front Mol Neurosci 4:27. CrossRef Medline

Diamond JS, Grimes WN (2014) Distributed parallel processing in retinal amacrine cells. In The computing dendrite: from structure to function (Cuntz H, Remme MWH, Torbein-Nielsen B, eds), pp 191-204. New York, Heidelberg: Springer.

Dong CJ, Hare WA (2003) Temporal modulation of scotopic visual signals by A17 amacrine cells in mammalian retina in vivo. J Neurophysiol 89: 2159-2166. CrossRef Medline

Eggers ED, Lukasiewicz PD (2006) Receptor and transmitter release properties set the time course of retinal inhibition. J Neurosci 26:9413-9425. CrossRef Medline

Eggers ED, Lukasiewicz PD (2011) Multiple pathways of inhibition shape bipolar cell responses in the retina. Vis Neurosci 28:95-108. CrossRef Medline

Ghosh KK, Haverkamp S, Wässle H (2001) Glutamate receptors in the rod pathway of the mammalian retina. J Neurosci 21:8636-8647. Medline
Gowda K, Zinnanti WJ, LaNoue KF (2011) The influence of diabetes on glutamate metabolism in retinas. J Neurochem 117:309-320. CrossRef Medline

Grimes WN, Li W, Chávez AE, Diamond JS (2009) BK channels modulate pre- and postsynaptic signaling at reciprocal synapses in retina. Nat Neurosci 12:585-592. CrossRef Medline

Grimes WN, Zhang J, Graydon CW, Kachar B, Diamond JS (2010) Retinal parallel processors: more than 100 independent microcircuits operate within a single interneuron. Neuron 65:873-885. CrossRef Medline

Hancock HA, Kraft TW (2004) Oscillatory potential analysis and ERGs of normal and diabetic rats. Invest Ophthalmol Vis Sci 45:1002-1008. CrossRef Medline

Hanley JG (2014) Subunit-specific trafficking mechanisms regulating the synaptic expression of $\mathrm{Ca}^{2+}$-permeable AMPA receptors. Semin Cell Dev Biol 27:14-22. CrossRef Medline

Hartveit E (1999) Reciprocal synaptic interactions between rod bipolar cells and amacrine cells in the rat retina. J Neurophysiol 81:2923-2936. Medline

Hartveit E, Veruki ML (2007) Studying properties of neurotransmitter receptors by non-stationary noise analysis of spontaneous postsynaptic currents and agonist-evoked responses in outside-out patches. Nat Protoc 2:434-448. CrossRef Medline

Hartveit E, Veruki ML (2012) Electrical synapses between AII amacrine cells in the retina: function and modulation. Brain Res 1487:160-172. CrossRef Medline

Herrmann R, Heflin SJ, Hammond T, Lee B, Wang J, Gainetdinov RR, Caron MG, Eggers ED, Frishman LJ, McCall MA, Arshavsky VY (2011) Rod vision is controlled by dopamine-dependent sensitization of rod bipolar cells by GABA. Neuron 72:101-110. CrossRef Medline

Hull C, Li GL, von Gersdorff H (2006) GABA transporters regulate a standing $\mathrm{GABA}_{\mathrm{C}}$ receptor-mediated current at a retinal presynaptic terminal. J Neurosci 26:6979-6984. CrossRef Medline

Kolb H (1979) The inner plexiform layer in the retina of the cat: electron microscopic observations. J Neurocytol 8:295-329. CrossRef Medline

Kolb H, Famiglietti EV (1974) Rod and cone pathways in the inner plexiform layer of cat retina. Science 186:47-49. CrossRef Medline

Koulen P, Fletcher EL, Craven SE, Bredt DS, Wässle H (1998a) Immunocytochemical localization of the postsynaptic density protein PSD-95 in the mammalian retina. J Neurosci 18:10136-10149. Medline

Koulen P, Garner CC, Wässle H (1998b) Immunocytochemical localization of the synapse-associated protein SAP102 in the rat retina. J Comp Neurol 397:326-336. CrossRef Medline

Liu SJ, Cull-Candy SG (2005) Subunit interaction with PICK and GRIP controls $\mathrm{Ca}^{2+}$ permeability of AMPARs at cerebellar synapses. Nat Neurosci 8:768-775. CrossRef Medline

Lopes de Faria JM, Katsumi O, Cagliero E, Nathan D, Hirose T (2001) Neurovisual abnormalities preceding the retinopathy in patients with longterm type 1 diabetes mellitus. Graefes Arch Clin Exp Ophthalmol 239: 643-648. CrossRef Medline

Magazanik LG, Buldakova SL, Samoilova MV, Gmiro VE, Mellor IR, Usherwood PN (1997) Block of open channels of recombinant AMPA receptors and native AMPA/kainate receptors by adamantane derivatives. J Physiol 505:655-663. CrossRef Medline

Mørkve SH, Veruki ML, Hartveit E (2002) Functional characteristics of non-NMDA-type ionotropic glutamate receptor channels in AII amacrine cells in rat retina. J Physiol 542:147-165. CrossRef Medline

Murnick JG, Dubé G, Krupa B, Liu G (2002) High-resolution iontophoresis for single-synapse stimulation. J Neurosci Methods 116:65-75. CrossRef Medline

Nelson R, Kolb H (1985) A17: a broad-field amacrine cell in the rod system of the cat retina. J Neurophysiol 54:592-614. Medline

Ng YK, Zeng XX, Ling EA (2004) Expression of glutamate receptors and calcium-binding proteins in the retina of streptozotocin-induced diabetic rats. Brain Res 1018:66-72. CrossRef Medline

Osswald IK, Galan A, Bowie D (2007) Light triggers expression of philanthotoxin-insensitive $\mathrm{Ca}^{2+}$-permeable AMPA receptors in the developing rat retina. J Physiol 582:95-111. CrossRef Medline

Palmer MJ (2006) Functional segregation of synaptic $\mathrm{GABA}_{\mathrm{A}}$ and $\mathrm{GABA}_{\mathrm{C}}$ receptors in goldfish bipolar cell terminals. J Physiol 577:45-53. CrossRef Medline

Pardue MT, Barnes CS, Kim MK, Aung MH, Amarnath R, Olson DE, Thulé PM (2014) Rodent hyperglycemia-induced inner retinal deficits are 
mirrored in human diabetes. Transl Vis Sci Technol 3:6. CrossRef Medline

Pologruto TA, Sabatini BL, Svoboda K (2003) ScanImage: flexible software for operating laser scanning microscopes. Biomed Eng Online 2:13. CrossRef Medline

Ramsey DJ, Ripps H, Qian H (2006) An electrophysiological study of retinal function in the diabetic female rat. Invest Ophthalmol Vis Sci 47:51165124. CrossRef Medline

Ramsey DJ, Ripps H, Qian H (2007) Streptozotocin-induced diabetes modulates GABA receptor activity of rat retinal neurons. Exp Eye Res 85:413422. CrossRef Medline

Reis A, Mateus C, Melo P, Figueira J, Cunha-Vaz J, Castelo-Branco M (2014) Neuroretinal dysfunction with intact blood-retinal barrier and absent vasculopathy in type 1 diabetes. Diabetes 63:3926-3937. CrossRef Medline

Reiter CE, Gardner TW (2003) Functions of insulin and insulin receptor signaling in the retina: possible implications for diabetic retinopathy. Prog Retin Eye Res 22:545-562. CrossRef Medline

Sakai H, Tani Y, Shirasawa E, Shirao Y, Kawasaki K (1995) Development of electroretinographic alterations in streptozotocin-induced diabetes in rats. Ophthalmic Res 27:57-63. CrossRef Medline

Santiago AR, Rosa SC, Santos PF, Cristóvão AJ, Barber AJ, Ambrósio AF (2006) Elevated glucose changes the expression of ionotropic glutamate receptor subunits and impairs calcium homeostasis in retinal neural cells. Invest Ophthalmol Vis Sci 47:4130-4137. CrossRef Medline

Santiago AR, Hughes JM, Kamphuis W, Schlingemann RO, Ambrósio AF (2008) Diabetes changes ionotropic glutamate receptor subunit expression level in the human retina. Brain Res 1198:153-159. CrossRef Medline

Semkova I, Huemmeke M, Ho MS, Merkl B, Abari E, Paulsson M, Joussen AM, Plomann M (2010) Retinal localization of the glutamate receptor GluR2 and GluR2-containing proteins in diabetic rats. Exp Eye Res 90: 244-253. CrossRef Medline

Sheng M, Sabatini BL, Südhof TC (2012) Synapses and Alzheimer’s disease. Cold Spring Harb Perspect Biol 4:a005777. CrossRef Medline
Simó R, Hernández C (2014) Neurodegeneration in the diabetic eye: new insights and therapeutic perspectives. Trends Endocrinol Metab 25:23-33. CrossRef Medline

Singer JH, Diamond JS (2003) Sustained $\mathrm{Ca}^{2+}$ entry elicits transient postsynaptic currents at a retinal ribbon synapse. J Neurosci 23:10923-10933. Medline

Stell BM, Mody I (2002) Receptors with different affinities mediate phasic and tonic $\mathrm{GABA}_{\mathrm{A}}$ conductances in hippocampal neurons. J Neurosci 22: RC223. Medline

Strettoi E, Raviola E, Dacheux RF (1992) Synaptic connections of the narrow-field, bistratified rod amacrine cell (AII) in the rabbit retina. J Comp Neurol 325:152-168. CrossRef Medline

Swanson GT, Kamboj SK, Cull-Candy SG (1997) Single-channel properties of recombinant AMPA receptors depend on RNA editing, splice variation, and subunit composition. J Neurosci 17:58-69. Medline

Traynelis SF, Wollmuth LP, McBain CJ, Menniti FS, Vance KM, Ogden KK, Hansen KB, Yuan H, Myers SJ, Dingledine R (2010) Glutamate receptor ion channels: structure, regulation, and function. Pharmacol Rev 62:405496. CrossRef Medline

Verkhratsky A, Fernyhough P (2008) Mitochondrial malfunction and $\mathrm{Ca}^{2+}$ dyshomeostasis drive neuronal pathology in diabetes. Cell Calcium 44: 112-122. CrossRef Medline

Veruki ML, Mørkve SH, Hartveit E (2003) Functional properties of spontaneous EPSCs and non-NMDA receptors in rod amacrine (AII) cells in the rat retina. J Physiol 549:759-774. CrossRef Medline

Weiss JH (2011) $\mathrm{Ca}^{2+}$ permeable AMPA channels in diseases of the nervous system. Front Mol Neurosci 4:42. CrossRef Medline

Yasuda R, Nimchinsky EA, Scheuss V, Pologruto TA, Oertner TG, Sabatini BL, Svoboda K (2004) Imaging calcium concentration dynamics in small neuronal compartments. Sci STKE 2004:p15. CrossRef Medline

Zoghbi HY, Bear MF (2012) Synaptic dysfunction in neurodevelopmental disorders associated with autism and intellectual disabilities. Cold Spring Harb Perspect Biol 4:a009886. CrossRef Medline 